\title{
A PROTEIN-STAT MECHANISM FOR REGULATION OF GROWTH AND MAINTENANCE OF THE LEAN BODY MASS
}

\author{
D. JOE MILLWARD
}

Centre for Nutrition and Food Safety, School of Biological Sciences, University of Surrey, Guildford GU2 5XH

\section{CONTENTS}

INTRODUCTION AND NATURE OF THE PROBLEM . . . . . . 93

DIETARY PROTEIN AND GROWTH CONTROL MECHANISMS . . 94

GENETIC DETERMINATION . . . . . . . . . . . . . . 94

FUNCTIONAL DEMAND . . . . . . . . . . . . . . . . 95

NUTRITION: PERMISSIVE AND ACTIVE INFLUENCES. . . . . . . . . 96

DIETARY PROTEIN AND REGULATION OF LINEAR GROWTH . . 96

CELLULAR MECHANISMS OF LINEAR BONE GROWTH REGULATION . . 98

REGULATION OF SKELETAL MUSCLE GROWTH AND

MAINTENANCE . . . . . . . . . . . . . . 99

MUSCLE MASS-LENGTH GROWTH RELATIONSHIPS: NORMAL MUSCLE

GROWTH . . . . . . . . . . . . . . . . . 99

MALNUTRITION AND SKELETAL MUSCLE GROWTH FAILURE . . . . . 100

CATCH-UP GROWTH OF MUSCLE. . . . . . . . . . . . . 102

CELlular MECHANiSMS OF MUSCle GROWTH REgUlation. . . . 103

STABILITY OF MUSCLE MASS. . . . . . . . . . . . . . 105

CHRONIC STABILITY

ACUTE STABILITY: DIURNAL CYCLING . . . . . . . . . . . . 107

CELLULAR MECHANISMS FOR THE LIMITATION OF MUSCLE GROWTH . . 107

SUMMARY OF SKELETAL MUSCLE GROWTH REGULATION . . . . . 109

FOOD INTAKE REGULATION AND LEAN TISSUE GROWTH . . . 109

ANIMAL STUDIES . . . . . . . . . . . . . . . . . . . 109

HUMAN STUDIES.$\quad \cdot$.

CELlular MECHANISMS OF AMINOSTATIC APPETITE REgUlation • • 112

THE PROTEIN-STAT AND WHOLE BODY GROWTH COORDINATION 115

REFERENCES . . . . . . . . . . . . . . . 117

\section{INTRODUCTION AND NATURE OF THE PROBLEM}

This review is concerned with growth control at the level of the whole organism, i.e. the interplay between internal biological mechanisms and external influences which together result in coordinated whole body growth. The problem under consideration is the mechanism which allows that coordination at the level of the control of the growth of tissue 
and organ protein content. However, for the slow-growing long-lived human, with most of life span spent in the adult state after growth has stopped, any mechanism of growth control must also address the issue of body weight maintenance; i.e. the remarkable phenomenon of the long term constancy of the body protein content at a characteristic size. The questions here are the identity of the regulatory mechanisms which allow restoration of body weight to its target size after an insult which induces wasting, i.e. catch-up growth, and the mechanisms which prevent the continuation of growth after that target size has been reached. These questions have not been previously widely discussed, but are examined here in the context of a mechanism, described as a protein-stat, operating at the level of matching dietary protein intake to the demands of filling the body protein store to a specific level, i.e. increasing protein intake when body protein is depleted and limiting it on repletion. The focus will be on the protein content of skeletal muscle as the main regulated body protein mass with control acting to maintain whole body muscle protein content at a characteristic size. The hypothesis will be developed that the central feature of biological growth regulation is an interaction between linear growth of bone, protein deposition in skeletal muscle and dietary protein intake, with the growth of most other organs secondary to this interaction. At present, understanding of such a mechanism is limited. The basis of the hypothesis is the phenomenology of human and animal growth, most of which is well known, and emerging experimental information which is allowing light to be shed on the detailed cellular mechanisms which must be identified if the hypothesis is to be more than an interesting idea. No claims are made about the comprehensiveness of the protein-stat mechanism for explaining all growth and body weight maintenance control. However, it is to be hoped that sufficient evidence can be presented to show that such a mechanism does exist and has to be at the centre of such control.

The structure of this review is an examination of what is known about (i) the nutritional regulation of growth, both normal and catch-up growth, especially of bone and skeletal muscle and their inter-relationships, (ii) the day-to-day maintenance of body protein, (iii) the regulation of dietary protein intake, and (iv) the implications of this in terms of a protein-stat mechanism.

\section{DIETARY PROTEIN AND GROWTH CONTROL MECHANISMS}

The starting point for the development of a protein-stat concept is within the nutritional component of the overall regulatory mechanism of growth control, as shown in Fig. 1. For the purpose of this review, growth is defined as irreversible structural change, i.e. the irreversible transformation of dietary substrates and tissue energy stores into tissue and organ structures such as bone and connective tissue, with the reversible deposition of cellular protein lumped with triacylglycerol and glycogen deposition and described as energy storage. This scheme brings together the three principal determinants of growth control, i.e. genetic determination, functional demand and nutrition which, together with the metabolic demand for fuel, determine overall nutrient demand, with appetite control allowing substrate intake to match the demand.

\section{GENETIC DETERMINATION}

The growth potential of an individual in height and overall shape, i.e. mainly bone growth, is genetically determined and each individual will follow a growth curve canalized in terms of both extent and time course if conditions are favourable (Tanner, 1986). When interrupted by malnutrition or infection there is usually some period of catch-up growth in 


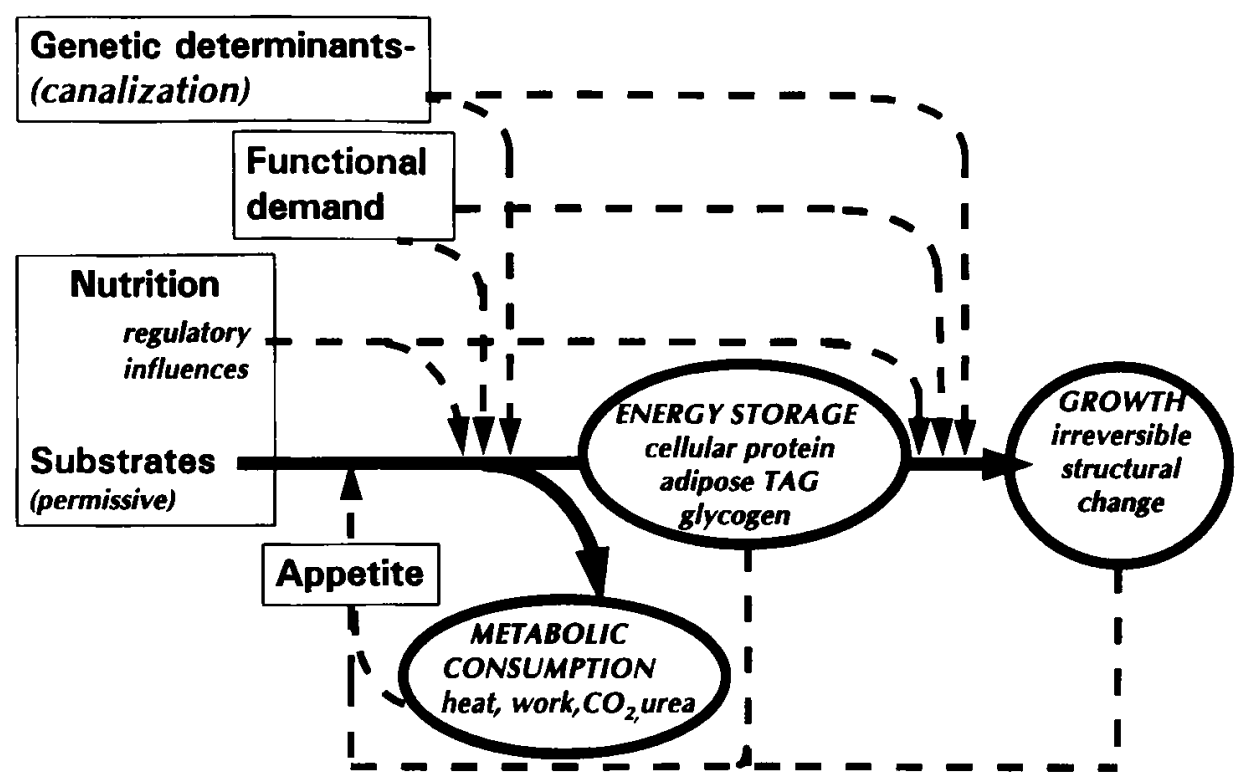

Fig. 1. Regulatory mechanisms of growth control. Growth control is shown as the regulation, by genetic determinants and functional demand, of nutrient substrate flow into energy storage, growth (defined here as irreversible structural change) and metabolic consumption. Since nutrition also exerts active regulation in terms of specific dietary influences on anabolic processes involved in both energy storage and growth, nutrition exerts both permissive and active regulation. TAG, triacylglycerol.

weight for height (Ashworth, 1974; Ashworth \& Millward, 1986; Waterlow, 1992) and in height for age (Golden, 1994), i.e. a self-correcting response returning the growth pattern to the individual growth channel. It is likely that the extent of energy storage in terms of adiposity and especially muscularity is also largely genetically determined.

\section{FUNCTIONAL DEMAND}

In general the size of organs and tissues involves responses to the functional demands made on them (Goss, 1978). The examples cited are regulation of erythrocyte production in bone marrow by kidney derived erythropoietins in response to decreased oxygen levels or increased oxygen consumption; compensatory kidney and hepatic hypertrophy after unilateral nephrectomy and partial hepatectomy; and thyroid gland hypertrophy with iodine deficiency due to increased output of thyroid stimulating hormone. However, here the important functional responses are the increase in protein content of the liver and most visceral organs in response to increased food intake, which in turn is regulated largely by the metabolic demand generated by the energy needs for maintenance and external work. In this sense there is less of a need to define specific mechanisms to regulate their size.

As for skeletal muscle, Goss identifies the increase in size with strenuous exercise and atrophy with disuse. However, as discussed below, while disuse atrophy is well known with the corollary that physical activity is required to maintain maximal muscle mass, muscle hypertrophy with increased physical activity may not be an appropriate example of growth through functional demand. Thus in contrast to the muscle hypertrophy observed with increased demand in experimental models (Laurent \& Millward, 1980), increased muscle mass does not accompany increased muscle activity in humans, occurring only in response to a very limited range of high load activities. This means that any protein-stat mechanism 
must explain not only normal muscle growth but also the prevention of the expansion of skeletal muscle beyond its canalized size.

\section{NUTRITION: PERMISSIVE AND ACTIVE INFLUENCES}

The protein-stat is a major component of the nutritional regulation of growth. While it is self-evident that there is a permissive influence of nutrition on growth, growth is clearly not a simple or necessary consequence of substrate provision. This means that there is a need for specific active nutritional regulatory influences (at least for protein deposition) which allow storage and growth, and such mechanisms are initiated by specific dietary constituents. Thus food stimulates energy storage and growth through specific acute and chronic regulatory influences which are independent of simple provision of substrates. The fact that growth failure occurs in conditions associated with endocrine abnormalities (e.g. type I diabetes, dwarfism) identifies the need for intact hormonal systems which link food intake to growth control.

Dietary protein is a key active nutritional regulator. On the basis of the established regulatory influence of protein intake on muscle growth in the rat, Millward \& Rivers $(1988,1989)$ proposed that dietary amino acids had an active influence on growth which they defined as the anabolic drive. The central role of insulin together with thyroid hormones, growth hormone and insulin-like growth factor 1 (IGF-1) as mediators of the anabolic drive are discussed elsewhere (Millward \& Rivers, 1988, 1989; Millward, 1990, 1995). While the concept of an anabolic drive can be extended to several other key nutrients, such as zinc and other members of the class of growth limiting nutrients which Golden defines as Type 2 nutrients (Golden, 1988), dietary protein is almost certainly the most important mediator, exerting an anabolic drive, not only on skeletal muscle, but also on linear growth of bone.

\section{DIETARY PROTEIN AND REGULATION OF LINEAR GROWTH}

Current understanding of the nutritional regulation of linear human growth is poor. When variation and failure of linear growth occurs during the first 2 years of life, identifying nutritional aetiologies as opposed to infection and other environmental stress is extremely difficult (Martorell, 1985), as is the disentangling of macro and micronutrient deficiencies from inadequate fetal endowment with nutrients in utero (Allen, 1994). As far as dietary protein is concerned, while there is ample evidence for an effect of skimmed milk supplementation on height growth in children (Golden, 1988), proof that it is the protein content per se which is responsible rather than some fellow nutrient traveller like zinc or calcium has not been obtained. Thus while studies of growth, diet, and urinary $\mathrm{N}$ excretion in elementary school children from urban and rural areas of Korea indicate that animal protein intake correlated most significantly with height-for-age (Paik et al. 1992), the actual nutrient responsible is not identified. A recent study does tend to support the assumption that it is an effect of dietary amino acids per se. Thus increasing the protein content of the diet from 7.5 to $15 \%$ energy during a 21 -day period of convalescence from shigellosis in children led to more rapid catch-up growth in height (Kabir et al. 1993) and this was associated with higher serum concentrations of IGF-1 (Kabir et al. 1992), known to be sensitive to amino acid intakes. Interestingly, studies comparing the relative influence of Quality Protein Maize with a modified cows' milk formula on catch-up growth in recovering malnourished children showed that linear growth and weight gain were not different (Graham et al. 1990). This maize, of the opaque genetic variant type, has increased lysine and tryptophan levels compared with normal maize, but nevertheless much lower levels of these indispensable amino acids than has milk. The similar height growth was 

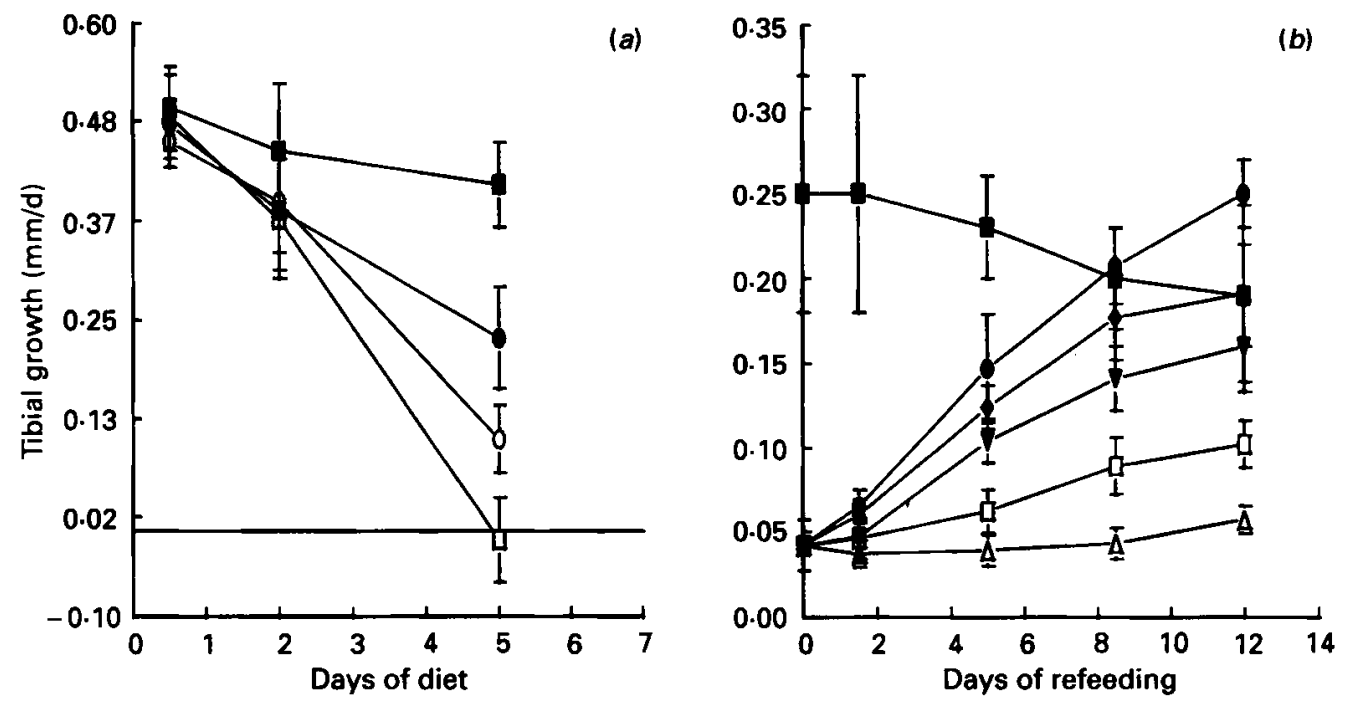

Fig. 2. Effects of dietary amino acids on bone growth. Total tibial length was measured radiographically (a) in rats in which growth inhibition was induced by ad lib. feeding of low protein diets for up to $7 \mathrm{~d}$, and $(b)$ in rats during catch-up growth on increasing dietary protein levels after complete growth inhibition (21 d of a $0.5 \%$ protein diet: Yahya \& Millward, 1994). Dietary protein : (a) $\square, 20 \% ; 0,7 \%$; O. $3.5 \% ; \square, 0.5 \% ;(b) \square, 20 \%$ age control; $, 20 \%, \diamond, 12 \% ; \nabla, 9 \% ; \square, 6 \% ; \triangle, 3 \%$.

observed even though the lower intakes of indispensable amino acid in the maize fed children resulted in lower postprandial plasma essential amino acids than did milk diets. Thus protein quality appears to be less important than protein level although this was largely catch-up growth which may be less dependent on dietary quality than conventional growth. Indeed, the findings are in contrast to earlier work suggesting that lysine intakes may be critically important for linear growth (Mack et al. 1962). Golden (1994) argues that the sulphur needs for sulphated proteoglycan synthesis in bone may mean that the sulphur amino acids are particularly important, but there is as yet little direct evidence.

Recent animal studies in the author's laboratory show clearly the specific effects of dietary protein on bone growth in the rat (Fig. 2; Yahya \& Millward, 1994). While marked slowing of length growth in response to protein deficiency was delayed for at least 3 days, after this time there were graded reductions with reduced protein intakes. A similar dependence on dietary protein levels was observed during refeeding. Catch-up growth in weight commenced immediately in most dietary groups but bone growth recovered slowly at a rate which reflected the dietary protein intake over the complete range of protein intakes. Most importantly, differences in length growth occurred between the three highest intakes $(9,12$ and $20 \%$ protein), even though the rate of body weight and muscle growth was maximal at $9 \%$ protein and did not differ markedly between these levels. Thus the influence of dietary amino acids on bone length growth can be observed at intakes above those necessary to ensure maximal rates of protein accretion.

These influences of dietary protein on linear bone growth seem more powerful than influences exerted by energy intake. While food restriction has long been known to inhibit linear growth (Dickerson \& McCance, 1961), the specific effects of energy deficiency, independently from protein deficiency, have been relatively unexplored. Fig. 3 shows recent studies of the influence of dietary energy restriction and corticosterone, a mediator of severe energy deficiency, on long bone growth (Tirapegui et al. 1994). In 4-day starved, severely energy restricted rats and corticosterone treated rats, while weight loss occurred in all 

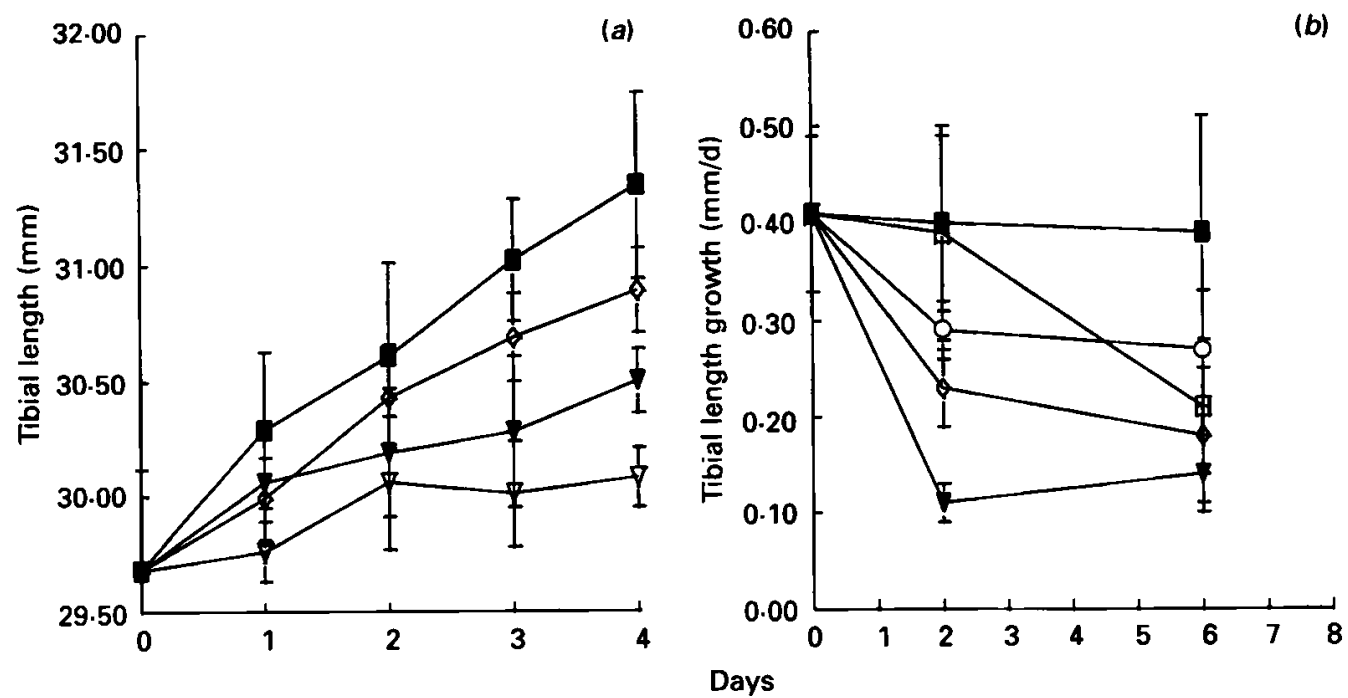

Fig. 3. Effects of dietary energy restriction and corticosterone (CS) on bone growth (Tirapegui et al. (1994). Energy restricted diets comprised increased protein concentrations to maintain constant protein intakes. Corticosterone, $100 \mathrm{mg} / \mathbf{k g}$ daily, resulted in plasma levels observed after prolonged starvation. Energy intake (\% ad lib.): (a) $\square$ ad lib.; $\diamond, 25 \% ; \nabla$, starved; $\nabla,+$ corticosterone. (b) $\square$, ad lib.; $\square$, $75 \% ; 0,50 \% ; \diamond, 25 \% ; \nabla$, corticosterone.

groups, tibial growth continued in the energy restricted and starved groups, albeit at reduced rates. In progressively food restricted rats fed constant protein intakes (i.e. diets containing increasing concentrations of protein), although body weight growth was arrested in all groups, with weight loss in the severely restricted rats, some tibial length growth continued at all levels of energy restriction with a slow development of inhibition. Only with corticosterone treatment was linear growth inhibited immediately. Interestingly, comparison of the relative influences of protein as opposed to energy deficiency on bone growth indicates protein deficiency to be the most powerful influence. Thus in the most severely energy restricted group ( $25 \%$ ad lib. intake), while body weight fell by $20 \%$ (Tirapegui et al. 1994), tibial length growth was similar to or even greater than in rats fed protein deficient diets ( 7 or $3.5 \%$ protein) for a similar period which were maintaining body weight.

Taken together these experimental data strongly support a dietary control mechanism for linear growth in which protein intake is the most powerful macronutrient influence.

\section{CELLULAR MECHANISMS OF LINEAR BONE GROWTH REGULATION}

Bone lengthening is the outcome of a complex series of events in the epiphyseal cartilage growth plate, requiring columnar chondrocyte proliferation, maturation and mineralization (endochondrial ossification: see Price et al. 1994b). There is in fact very little detailed information on the mechanisms by which nutrition and especially dietary protein can mediate changes in growth plate activity leading to changes in linear growth per se.

Recent studies in the author's laboratory have examined the extent to which changes in protein and proteoglycan synthesis $\left({ }^{35} \mathrm{~S}\right.$ uptake) in the growth plate are associated with changes in linear growth and may therefore be targets for the anabolic drive (Yahya et al. 1994). The studies showed that the delayed inhibition of tibial length growth by protein 
deficiency reflected the delayed inhibition of protein synthesis and ${ }^{35} \mathrm{~S}$ uptake measured in vivo. These responses are different from those associated with growth inhibition by energy deficiency or corticosteroids. In this case inhibition of length growth was dissociated from and preceded inhibition of protein synthesis and ${ }^{35}$ S uptake, which were only observed in the most severely restricted groups or after prolonged corticosterone treatment. Although the mechanism of the growth inhibition by energy deficiency was not definitely established, it was likely to involve an elevation of rates of proteolysis and proteoglycan degradation associated with elevated corticosterone levels.

As to the cellular mechanisms by which dietary protein signals anabolic changes in the growth plate, while growth hormone, IGF-1, IGF-1 binding proteins, thyroid hormones and vitamin $\mathrm{D}$ are all known to regulate chondrogenesis and chondrocyte maturation (Nilsson et al. 1994), the way dietary amino acid supply mediates changes in these hormones and their binding proteins is not known in detail (Yahya et al. 1990). Indeed, our studies showed a lack of correlation between plasma and tissue total extractable IGF-1 concentrations with the inhibition of bone growth and proteoglycan synthesis by protein deficiency, and indeed very little change in total IGF-1 during complete growth inhibition (Yahya et al. 1990). Thus IGF-1 action on bone growth is unlikely to involve simple endocrine or autocrine/paracrine mechanisms in which total extractable hormone in either plasma or the tissue determined the functional response.

To summarize then, while dietary protein has a clear, specific regulatory influence on bone growth, the cellular mechanisms of that influence remain to be discovered.

\section{REGULATION OF SKELETAL MUSCLE GROWTH AND MAINTENANCE}

Any discussion of whole body growth control must address the issue of skeletal muscle growth, since it is the largest component of the lean body mass (LBM). In the reference adult described by Forbes (1988), with the LBM accounting for between $85 \%$ body weight in the newborn and $70-85 \%$ in reference adults, skeletal muscle accounts for between $22 \%$ (neonate) and $40 \%$ (adult) of body weight. This is up to $50 \%$ of the mass (and protein content, given the similar protein concentrations in most organs) of the LBM and about $60 \%$ of the soft tissues. This proportion is higher in larger animals given the relative allometry of skeletal muscle and the other organs which results in an increasing proportion of skeletal muscle at the expense of visceral tissue with increasing body size (Munro, 1964).

The first question to address is the way muscle growth is regulated in relation to overall body size and especially the height (or length) of the organism.

\section{MUSCLE MASS-LENGTH GROWTH RELATIONSHIPS: NORMAL MUSCLE GROWTH}

The size of the lean body mass is a function of height at all ages, although there are marked sex differences. The average regression slope is $0.69 \mathrm{~kg} / \mathrm{cm}$ in adult males and $0.29 \mathrm{~kg} / \mathrm{cm}$ in adult women, and when the sexes are considered together LBM varies as the cube of the height (Forbes, 1988). With skeletal muscle increasing as a proportion of the LBM with age, skeletal muscle would be expected to vary with height to $>$ power 3 , and data collected on athletes shows that skeletal muscle varies as height to the power $4 \cdot 4$ (Forbes, 1988).

It would be expected that any regulatory mechanism of skeletal muscle growth would result in a growth pattern within the whole organism which is consistent with its physiological function, i.e. ensuring sufficient growth to maintain adequate muscle strength with increasing body weight. Recent measurements of the growth of an individual rat 


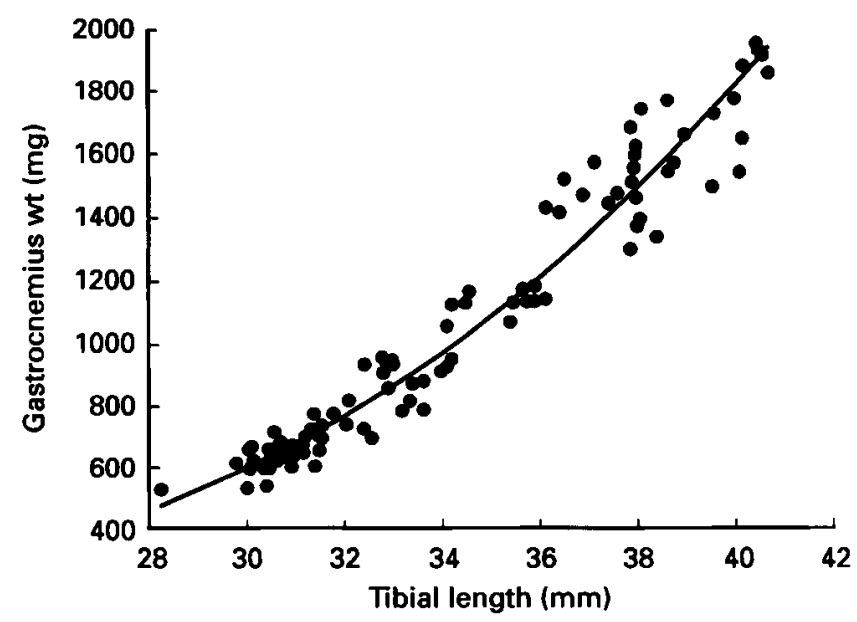

Fig. 4. Relationship between gastrocnemius muscle weight and tibial length in well fed rats. The line is the predicted muscle weight calculated from the linear regression of the log transformed data: i.e. $\mathrm{W}=\mathrm{L}^{3 \cdot 85} / 10^{2 \cdot 912}(n=96, r=0 \cdot 98)$ (Yahya \& Millward, 1994).

muscle in relation to the bone to which it is attached (Fig. 4) show that the weight of the gastrocnemius muscle varies as tibial length to the power 3.85 (Yahya \& Millward, 1994). Given that muscle strength mainly varies as the cross-sectional area, and that body volume and weight vary with length ${ }^{3}$, then for strength to increase in proportion to body weight, cross sectional area of muscle should vary with bone length ${ }^{3}$, with muscle weight varying as length ${ }^{4}$ as observed.

These relationships for this single muscle-bone pair do seem to be representative of a general relationship. Thus Parker et al. (1990) reported that in prepubertal boys and girls, strength of the elbow flexor muscle varied as height ${ }^{1.99}$, the exponent increasing to 2.93 during the male pubertal growth spurt. This is equivalent to weight/height exponents of 2.99 and 3.93, the latter value similar to our value for the rat. However, quadriceps strength varied as height ${ }^{3}$ (i.e. weight varying as height ${ }^{4}$ ), in boys and girls with little difference between pre or post puberty.

\section{MALNUTRITION AND SKELETAL MUSCLE GROWTH FAILURE}

Detailed information on linear bone growth-muscle weight growth interrelationships in humans is difficult to obtain but there is an emerging body of animal data which throws light on how muscle growth responds to changes in linear growth.

One of the surprising features of the response to undernutrition is that muscle growth appears to be less sensitive than other organs. Thus protein deficient rats can become leaner as the muscle weight/body weight ratio increases (Millward et al. 1975; Yahya \& Millward, 1994). In part this reflects a redistribution of body protein from skin to skeletal muscle (Waterlow et al. 1978). Only with the most severe protein deficiency does muscle growth stop immediately with subsequent actual loss. This would imply that in all but the most severely malnourished states there remains some anabolic stimulus for muscle growth. An important clue is the continuation of bone growth. Evidence that this occurs was recently reported (Yahya \& Millward, 1994; Tirapegui et al. 1994).

With ad lib. feeding of low protein diets which completely inhibited any body weight growth, inhibition of muscle growth was delayed, with significant increases in muscle mass and in the muscle-body weight ratio (by $20 \%$ in rats fed a $3.5 \%$ diet compared with 


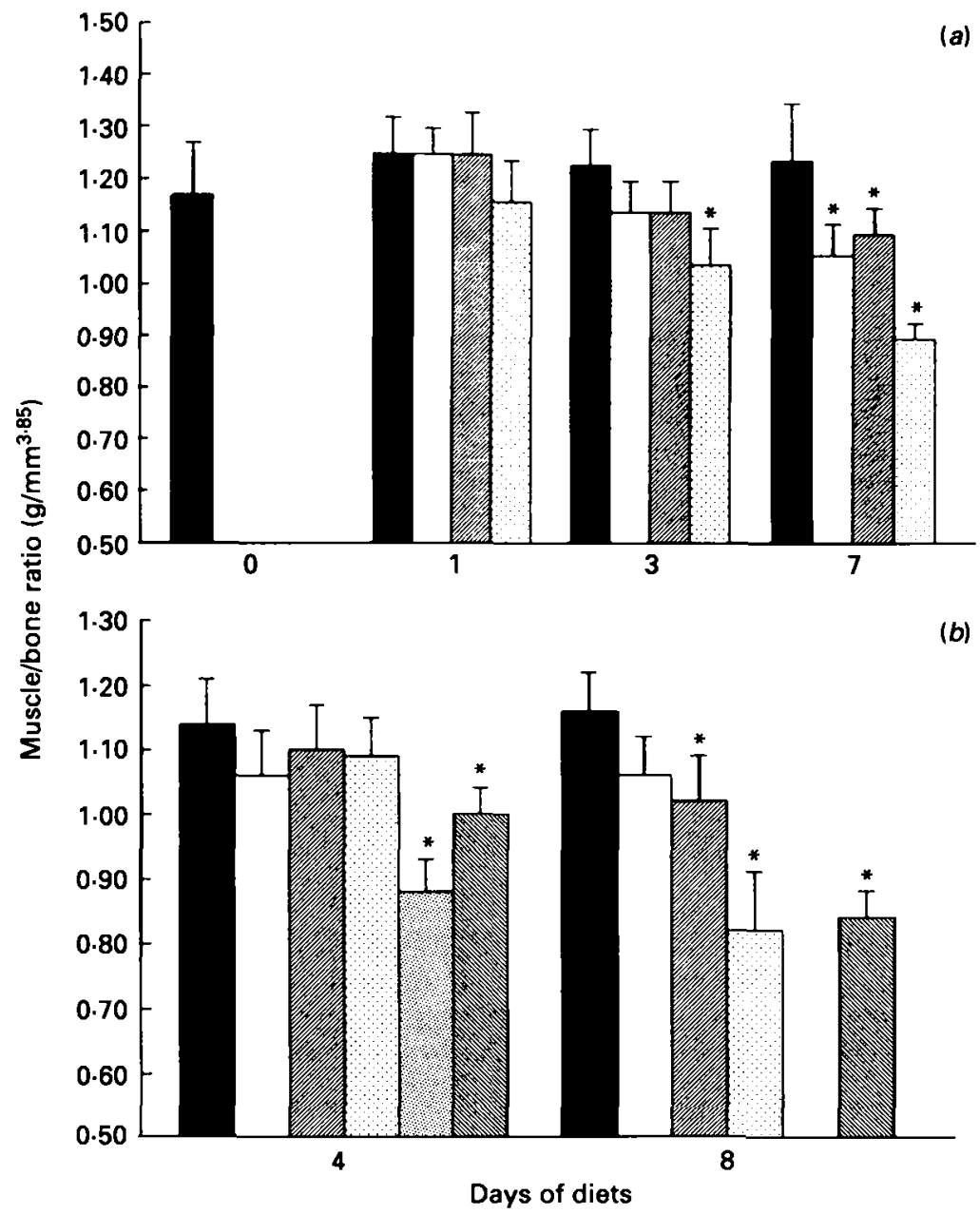

Fig. 5. Interrelationship of bone and muscle growth in response to growth inhibition by malnutrition. (a) Protein deficiency. Muscle bone ratio normalized according to the relationship shown in Fig. 5. A deficit in the muscle weight-bone length ratio was not apparent until $\mathrm{d} 7$ of the $3.5 \%$ and $7 \%$ protein deficient diets (Yahya \& Millward, 1994). $\square, 20 \% ; \square, 7 \% ; \square, 3.5 \%$; $0,0.5 \%$. (b) Energy deficiency. Muscle growth inhibition reflected tibial growth inhibition during the first $4 \mathrm{~d}$, with the muscle/bone ratio being maintained for all levels of energy restriction apart from starvation (Tirapegui et al. 1994).

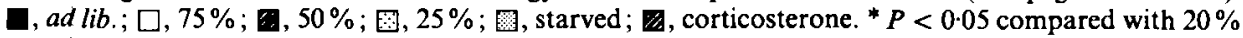
protein or ad lib. controls.

controls (Yahya \& Millward 1994). A significant deficit in the muscle weight-bone length ratio of all protein deficient groups was not apparent until after 7 days on diet (Fig. 5a). With energy deficiency or starvation, weight loss was also accompanied by an increase in the muscle-body weight ratio (Tirapegui et al. 1994). For all levels of energy restriction apart from starvation, muscle growth inhibition reflected tibial growth inhibition during the first 4 days, i.e. the muscle/bone ratio was maintained (Fig. $5 b$ ). In contrast, liver lost weight in all groups. Only with starvation or a catabolic dose of corticosteroids (i.e. additional direct inhibition of muscle growth), or longer periods of energy restriction, was muscle growth inhibition sufficient to induce a fall in the muscle weight-bone length ratio.

These results are consistent with muscle growth rate having an important dependency on 


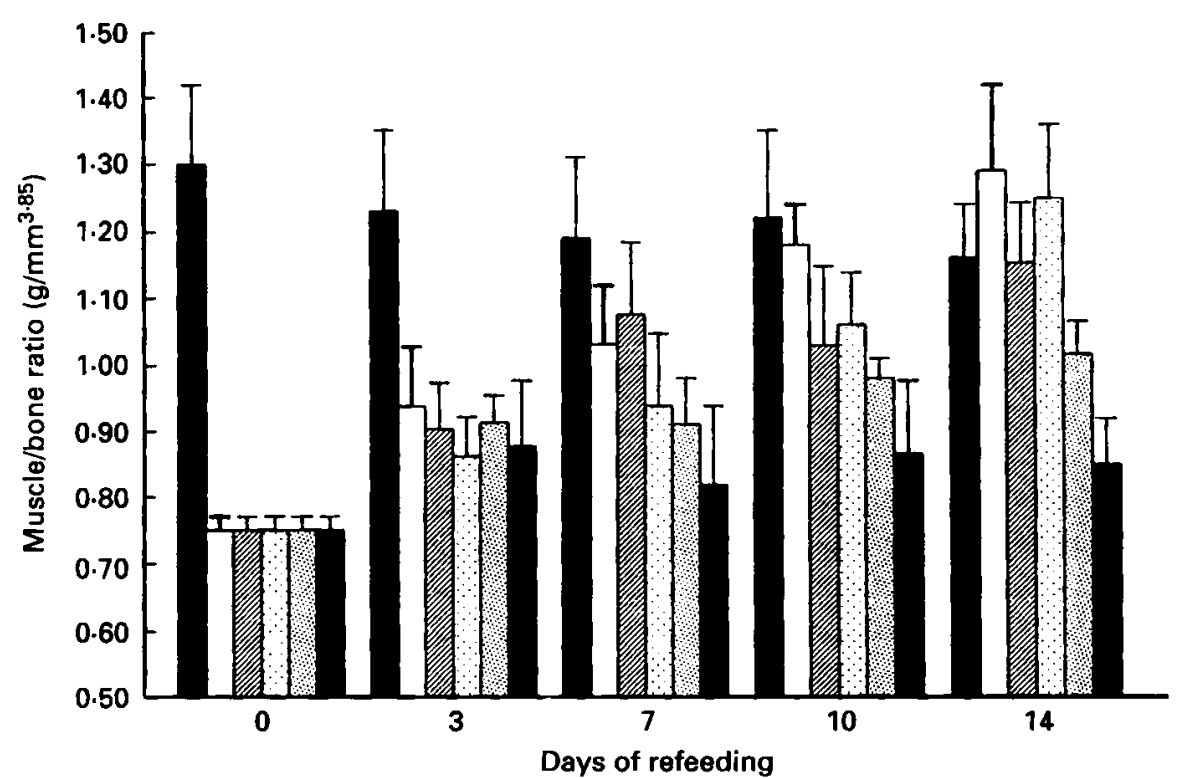

Fig. 6. Interrelationship of bone and muscle growth and dietary protein intake during catch-up growth. Animals were refed ad lib. after 21 d on a $0.5 \%$ protein diet (Yahya \& Millward, 1994). $\square$, Control; $\square$, $20 \%$; $12 \% ; 0,9 \%$; 圆, 6\%; $3 \%$.

bone length growth rate. Thus the delay in muscle growth inhibition relative to other organs is a reflection of the delay in bone growth inhibition, strongly suggesting a controlling influence of bone length growth on skeletal muscle growth. The influence is specific for muscle and does not extend to visceral organs such as liver.

\section{CATCH-UP GROWTH OF MUSCLE}

Catch-up growth in weight for height occurs when there is deficit of body weight of which skeletal muscle is an important component. In malnourished children the deficit in muscle results from either muscle wasting or inadequate growth in comparison to length growth (Ashworth, 1974; Ashworth \& Millward, 1986; Waterlow, 1992). Catch-up growth in weight can begin very quickly, with appropriate management, before catch-up growth in height can be detected. There is a marked stimulation of appetite, and growth proceeds at a rate limited only by food intake until the normal body weight for height is achieved. At this time there is a dramatic reduction in appetite and food intake so that growth slows to be subsequently limited by height growth. Since muscle mass is known to be depleted in the malnourished child, then to some extent catch-up growth can be viewed as an attempt to restore the deficit in muscle weight. The fact that acceleration of muscle growth can precede any restoration of length growth implies the existence of an anabolic potential not present after the appropriate muscle weight/length ratio has been achieved. The interrelationship of bone and muscle growth and dietary protein intake during catch-up growth is shown in Fig. 6 . The $40 \%$ deficit in muscle mass in relation to bone length did result in accelerated muscle growth, which commenced in advance of any detectable bone growth, with muscle repletion in relation to tibial length achieved at similar times at all dietary protein levels of $9 \%$ and above. With the lowest protein diet there was no significant repletion while with the $6 \%$ protein diet there was incomplete repletion. None of the rats exceeded the muscle mass-bone length ratio of well fed controls. 
Thus these studies extend the general dependency of skeletal muscle growth on bone length growth by showing that there is a specific target muscle size in relation to bone length which will be restored following an insult which has reduced muscle size below that target, as long as the dietary protein concentration is sufficient to exert an anabolic drive (i.e. $>6 \%$ protein in the rat). In other words growth in bone length acts as a controlling influence on both the rate (as in normal growth) and extent (as in catch-up growth) of muscle growth.

However, it is likely that in addition to passive stretch, there is an additional regulatory influence needed to ensure maximal muscle size. Thus in malnourished children the evidence would indicate that complete recovery of depleted muscle does not occur during the rapid weight gain phase (see Jackson \& Wooton, 1990). While muscle mass doubled in malnourished children during complete weight-height recovery (Picou et al. 1976), recovery of muscle was incomplete as judged by biochemical measurements of protein/DNA ratios, anthropometry (Brooke \& Wheeler, 1976) and histologicalmorphometric studies of fibre diameters (Hansen-Smith et al. 1979). There are several possible explanations for this. One is nutritional and related to the possible limitation of lean tissue growth by dietary zinc at very high growth rates. Thus Golden (1988) argues that the demands for zinc during catch-up growth are so high that, in the absence of specific supplementation of feeds, it may limit muscle growth. This is particularly the case with soya based formulae but also occurs with milk. Supplementation of the feeds does increase lean tissue deposition but it has not been shown that this would entirely explain the incomplete catch-up of muscle (Golden \& Golden, 1985).

Another possibility relates to the need for physical activity to enable the phenotypic skeletal muscle mass to be expressed. The malnourished child in hospital is not as physically active as in the home environment and Viteri \& Torun (1981) have shown that restricted physical activity impairs growth of the LBM in both rats and children. Thus with a programme of games aimed at increasing physical activity in malnourished children during recovery, the growth did appear to result in increased lean tissue and especially skeletal muscle gain as indicated by an increased creatinine-height index.

\section{CELLULAR MECHANISMS OF MUSCLE GROWTH REGULATION}

In the context of skeletal muscle protein as the regulated component of the protein-stat, there is considerable information on how amino acids and hormones mediate acute dietary influences on accretion of muscle proteins at the level of protein synthesis, including both ribosomal capacity and activity, and on proteolysis (Millward \& Waterlow, 1978; Waterlow et al. 1978; Jepson et al. 1988; Millward \& Rivers, 1988, 1989; Millward, 1995).

Given the experimental data relating to stretch induced hypertrophy (Laurent \& Millward, 1980), in which both active and passive stretch is known to mediate anabolic and anticatabolic influences (e.g. Goldspink et al. 1991), and given the relationship between tibial length and muscle weight as discussed above, it is likely that the passive muscle stretching by bone lengthening constitutes an important biological control of normal muscle growth. Muscle is not unique in this respect since mechanical forces are now recognized as powerful influences on growth of the uterus, lung, cardiovasculature and heart and the vasculature in general (Bishop et al. 1995). Many of the cellular changes involved in skeletal muscle hypertrophy in response to mechanical stimulation are being revealed with recent experimental work focusing on satellite cell proliferation (Allen \& Rankin, 1990; Winchester \& Gonyea, 1992), myofibrillar gene expression (Essig et al. 1991; Russell et al. 1992), myofibrillogenesis (Dix \& Eisenberg, 1990) and the signal transduction pathways which relate to these processes (Sadoshima \& Izumo, 1993) which involve 
increased expression and production of IGF-1 within the muscle fibres (Yan et al. 1993). Bishop et al. (1995) have reviewed the three principal mechanisms involved in translating the mechanical signals of passive stretch into cellular activity. Cytoskeletal energy transfer involves a direct transmission of the mechanical force from the extracellular matrix to intracellular protein synthesis at ribosomal and nuclear levels through integrin receptors on the cell surface and the associated intracellular cytoskeleton microtubular system. Stretch activated ion channels which mediate influx of $\mathrm{Na}^{+}$and $\mathrm{Ca}^{2+}$ and a range of subsequent intracellular signal transductions are thought to initiate mechanotransduction in some (but not all) cell types. Stimulation of membrane bound enzyme complexes involved in second messenger signal transduction, especially via adenylate cyclase (EC 4.6.1.1) and phospholipase $C$ (EC 3.1.4.3), is the third major mechanism with stimulation of immediate early genes (oncogenes such as c-fos) and cellular replication. Associated with these responses are increased growth factor release which includes transforming growth factor $\beta$, an important collagen stimulating growth factor and IGF-1. In studies of stretch induced skeletal muscle hypertrophy in the avian weighted wing model (Laurent $e t$ al. 1978), stimulation of collagen synthesis was seen to be an early event.

Stimulation of connective tissue synthesis is likely to be an important target of any stretch induced stimulus for normal muscle growth. This is because some remodelling of muscle connective tissue which constitutes a potential upper limit to myofibre volume must occur if myofibre diameters are to increase during normal growth. Experimentally this can be examined by measuring the synthesis of proteoglycans in muscle since these occur predominantly within the connective tissue sheath surrounding the myofibres (Gould, 1973). Recent studies of the dietary regulation of muscle and bone protein and proteoglycan synthesis indicated an apparent separate regulation of muscle proteoglycan synthesis $\left({ }^{35} \mathrm{~S}\right.$ uptake) from that of protein synthesis (Yahya et al. 1994). Thus changes in ${ }^{35} \mathrm{~S}$ uptake were unrelated to the acute diet induced changes in muscle weight growth, i.e. in contrast to the immediate inhibition of protein synthesis with protein deficiency, ${ }^{35} \mathrm{~S}$ uptake continued unchanged for at least $24 \mathrm{~h}$ after the diet change, continuing in some protein deficient groups at high rates after muscle growth had ceased. Marked inhibition was observed only after a period of severe protein deficiency. This points to a different control mechanism acting to regulate connective tissue synthesis separately from protein synthesis in the myofibre. Passive muscle stretching is the obvious candidate.

With passive stretching of muscle a function of tibial length growth at the time, muscle proteoglycan synthesis would be predicted to vary with the rate of bone length growth. While actual confirmation of this would require experimental interventions to alter bone length and muscle growth, if it is occurring, in vivo rates of muscle proteoglycan synthesis should vary with tibial length growth. In fact tibial growth was clearly correlated with muscle ${ }^{35} \mathrm{~S}$ uptake $(r=0 \cdot 84, n=174)$. Partial correlation analysis of the rates of muscle protein and ${ }^{35} \mathrm{~S}$ uptake in relation to dietary protein intake and tibial growth during the initial slowing of muscle growth with protein deficiency clearly indicates the separate influences (Fig. 7). While both protein synthesis and ${ }^{35} \mathrm{~S}$ uptake in muscle were related to tibial length growth, only protein synthesis was related to dietary protein intake. Thus the specific reduction in ${ }^{35} \mathrm{~S}$ uptake in muscle as tibial length growth slows is consistent with connective tissue synthesis in muscle being an important target process during the overall activation of muscle growth by passive stretching. Furthermore, in contrast to the findings in bone discussed above, in skeletal muscle there was a near complete proportionality in changes in tissue IGF-1 and ${ }^{35} \mathrm{~S}$ uptake (Yahya et al. 1990). This is consistent with an autocrine/paracrine role for IGF-1 in the regulation of muscle connective tissue synthesis, suggesting that total extractable IGF-1 in muscle is a good index of IGF-1 functional status. Why this should be the case in muscle but not in bone is not clear. IGF-1 binding 


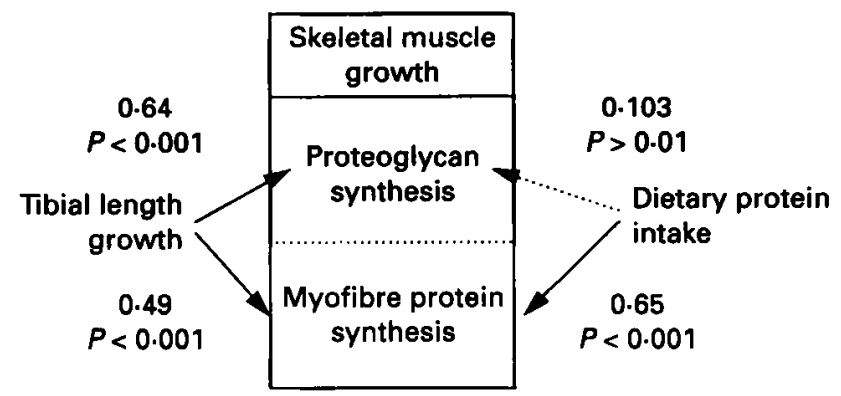

Fig. 7. Interactions between dietary protein and tibial growth and muscle protein and proteoglycan synthesis. Values shown are partial correlation coefficients $(n=60)$, determined between the four variables (dietary protein intake, muscle protein synthesis, muscle ${ }^{35} \mathrm{~S}$ uptake and bone growth) during the first $3 \mathrm{~d}$ of protein deficiency, in rats fed 20, 7, 3.5 and $0.5 \%$ protein diets ad lib. (Yahya et al. 1994).

proteins which may determine IGF-1 action have been described in muscle (McCusker \& Clemmons, 1988) as well as bone. However the suggestion has been made that differences in the local production of binding proteins affords the possibility of tissue specificity in IGF-1 action (Mohan et al. 1990). Whatever the detailed mechanisms of IGF-1 action the data suggest that IGF-1 production in skeletal muscle may be involved in mediating the response to passive stretch.

Overall, these experimental data are consistent with a muscle growth control mechanism in which protein deposition within the myofibre is mediated by both rapid direct dietary effects (amino acids, insulin and other anabolic growth factors) and passive stretch. In contrast, control of the growth of connective tissue in muscle would appear to be mainly under the anabolic influence of stretch, and this could be an important component of the coordination of muscle and bone length growth. Clearly, given the influence of androgens on skeletal muscle growth both in mediating the pubertal skeletal muscle growth spurt in boys and in mediating hypertrophy in adults consuming pharmacological doses, it must be assumed that the influence of passive stretch can be modified by androgenic steroid hormones.

\section{STABILITY OF MUSCLE MASS}

As indicated at the outset of this review, any general theory to account for the regulation of body protein mass must explain its long term stability in the adult. Thus there is a need for a mechanism to account for maintenance of a phenotypic body protein size at which regulation is exerted and which cannot be exceeded.

\section{CHRONIC STABILITY}

The extent to which there can be variation of the LBM height ratio during normal growth in well fed children is poorly understood. Recent studies of the growth of formula fed infants compared with breast fed infants during the first 6 months of life suggest that there can be some variation. Thus in formula fed infants the generally higher protein intakes compared with breast fed infants are associated with greater absolute gains in weight and lean body mass, more weight and lean body mass per gram protein intake, but similar rates of length growth (Heinig et al. 1993). In the context of the protein-stat this would imply that the breast fed infant is nutritionally limited and not able to achieve its maximum potential for lean tissue growth. However, there is no evidence that this represents any long term disadvantage for the breast fed infant and, as discussed by Heinig et al. (1993), it 


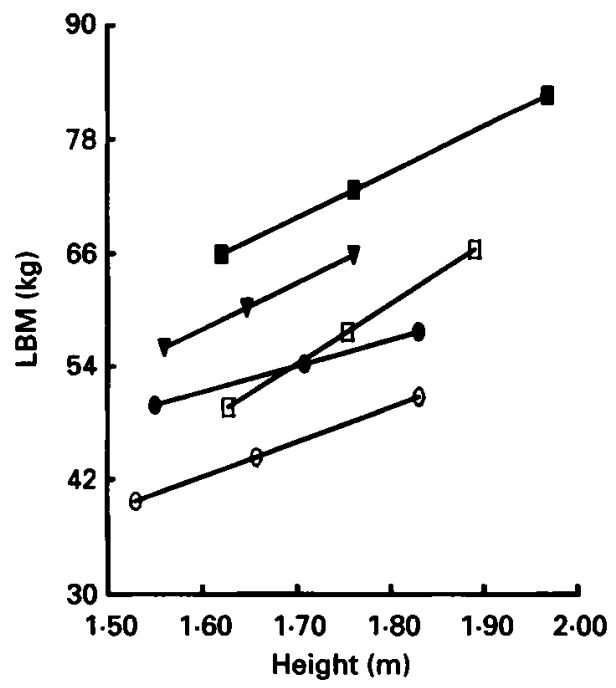

Fig. 8. Regressions of lean body mass on height in adult men and women. Values plotted between the minimum and maximum heights within each group and with group mean values shown; $\square$, males; 0 , females; $\square$, male athletes; 0 , female athletes; $\nabla$, obese. The athletes included elite rowers and natural body builders. (P. Pacy \& D. J. Millward, unpublished).

would be dangerous to draw conclusions about the relative desirability of what are in effect different time courses of growth of the LBM in children, in relation to long term health.

It is self-evident that in the human adult maintaining weight within remarkably small variation over long periods, the LBM is similarly maintained within narrow limits. However, the extent to which it is controlled at some upper limit is more difficult to quantify.

Firstly as with children, in the adult one component of muscle mass is dependent on a normal level of physical activity. Complete bed rest or lack of gravity is associated with loss of LBM although the magnitude of this component of the adult maximal skeletal muscle mass is not known with certainty. In male astronauts, after $84 \mathrm{~d}$ in zero gravity about $2.8 \mathrm{~kg}$ LBM were lost, i.e. $10 \%$ of total and up to a maximum of $20 \%$ of skeletal muscle (see Forbes, 1988).

As to expansion of the skeletal muscle mass, most measurements in adults have focused either on athletes or the obese. The expansion of the LBM in obesity is well documented although there is little documentation of the nature of that increase in terms of skeletal muscle as opposed to visceral organs. While autopsy data have shown larger hearts, livers and kidneys (Forbes, 1988), in one recent 100-d overfeeding study with young adult males, computerized tomography scanning was used to assess the changes in adipose tissue mass, skeletal muscle mass and non-muscular LBM, and it was shown that increases occurred in skeletal muscle but not non-muscle LBM (Deriaz et al. 1992).

The influence of physical activity is generally better documented although it remains difficult to quantify the extent of any increases in muscle mass with exercise. Forbes (1985) reviewed the evidence relating LBM to physical activity, emphasizing the influences of height, sex, obesity and ethnic origin, with LBM of Asians < Caucasians < Blacks. Calculation of any influence of physical activity on LBM needs to consider these variables. Measurements made on body builders (male and female) and elite rowers (male and female), all steroid free, and obese women as well as normal controls of both sexes are shown in Fig. 8 with the regressions of LBM on height plotted between the minimum and 
maximum heights and with group mean values shown (P. Pacy \& D. J. Millward, unpublished). The influences of sex, height and obesity are clearly apparent as is the greater LBM in the athletes. For the body builders a major part of the excess is a result of the high intensity training since they often have records of weight gain. However, for the rowers many report that their adult body weight has not substantially increased with training. Indeed, Forbes (1985) argues that athletes may simply be better endowed with skeletal muscle at the outset, since in longitudinal studies he was unable to demonstrate significant LBM accretion except where energy intake was excessive. He concluded that "exercise and/or training has not been shown to markedly increase lean body mass". He showed that only with the aid of steroids was appreciable gain achievable, reporting rates of gain of LBM in such body builders of up to $5.4 \mathrm{~kg}$ over 6 weeks, equivalent to about $0.3 \mathrm{~g}$ protein $/ \mathrm{kg}$ daily. On the basis of our experience with 'natural' body builders, while muscle gain is difficult, nevertheless with appropriate exercise regimes, including concentric contractions, significant muscle hypertrophy does occur but very slowly and with great difficulty.

\section{ACUTE STABILITY: DIURNAL CYCLING}

In the human adult, while there would appear to be a remarkable long term stability of the skeletal muscle mass and LBM; nevertheless there are marked acute changes which have important nutritional and physiological consequences and which raise important questions about how a protein-stat might operate.

The diurnal cycle of feeding and fasting characteristic of human nutrition results in gains and losses of body protein in subjects in overall nitrogen balance. Recent human studies have investigated these diurnal changes in nitrogen balance during consecutive 12-h periods of feeding and fasting, in subjects adapted to diets ranging from very low protein intakes $\left(0.36 \mathrm{~g} / \mathrm{kg}\right.$ daily) to very high levels $\left(2 \cdot 31 \mathrm{~g} / \mathrm{kg}\right.$ daily), with both $\mathrm{N}$ balance and $\left[{ }^{13} \mathrm{C}\right]$ leucine balance techniques. Diurnal gains and losses of body protein $\mathbf{N}$ were observed with an amplitude which increased with increasing dietary protein intakes (Price et al. 1994a). It is usually assumed that these fluctuations in body protein mass include changes in skeletal muscle. There are marked changes in amino acid uptake and release across human muscle during feeding and fasting although part of the exchange involves branched chain amino acid, alanine and glutamine, interconversions so that changes in actual protein balance are less than might be expected (Felig, 1981).

Clearly it would be very difficult to assess the precision with which a protein-stat regulates the restoration of muscle mass to its phenotypic size during the postprandial repletion of postabsorptive losses. The operation of a protein-stat within the diurnal cycle of gains and losses of increasing amplitude with increasing intakes is shown in Fig. 9. The assumption is made that total body protein mass is regulated at a slightly increasing level as the dietary protein intake increases due to a small expansion of splanchnic tissue protein mass.

\section{CELLULAR MECHANISMS FOR THE LIMITATION OF MUSCLE GROWTH}

As indicated above, a key feature of skeletal muscle growth appears to be that it is rate limited by connective tissue growth which controls myofibre diameter and length. How this is achieved at the cellular level is unknown. Thus while current research in cell biology can account for stimulation of muscle growth by stretching it is not immediately clear how expansion in myofibre volume is prevented in the absence of stretch. 


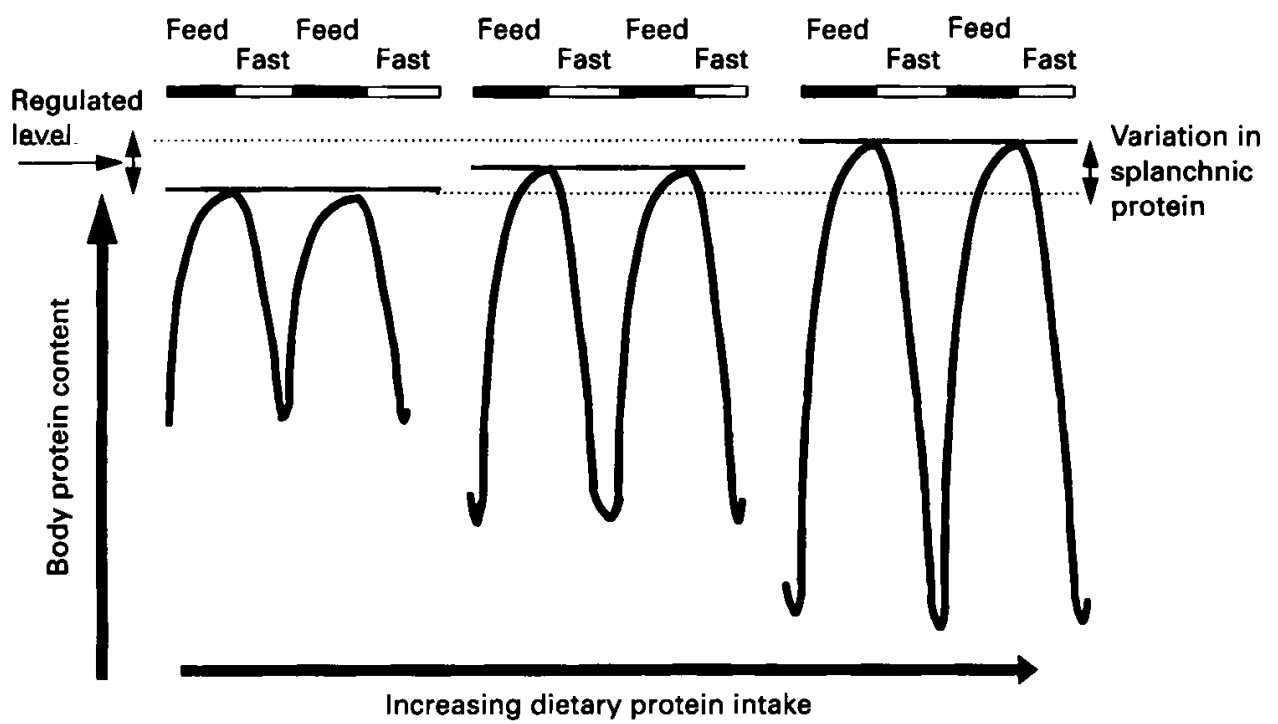

Fig. 9. The operation of the protein-stat within the diurnal cycle. The gains and losses of increasing amplitude with increasing intakes are shown with body nitrogen regulated at a slightly increasing level as the dietary protein intake increases owing to a small expansion of splanchnic tissue protein mass.

The author has briefly described a 'Bag-theory' of muscle growth regulation as the basis for a cellular mechanism (Millward, 1989). Thus the extracellular matrix (ECM) connective tissue sheath can be conceived as a series of bags which surround the individual myofibres (endomysium), bundles of myofibres, (perimysium), and the entire muscle (epimysium) (Gould, 1973). These bags act to conduct the contractile force, generated by the myofibrillar matrix and transmitted via the myofibre cytoskeleton, to the structures (usually bone) to which the muscle is attached by the tendons. With the ECM having minimum elasticity, muscle growth can be conceived as bag enlargement and bag filling. Bag enlargement is the connective tissue remodelling during length growth while bag filling is protein deposition within muscle myofibres which have a fixed volume (bag size) defined by the ECM. Indeed it is known that during muscle regeneration the endomysial sheath serves as guides for new fibres which grow from the stumps of old ones (Gould, 1973). Normal developmental muscle growth requires both bag filling and bag enlargement, i.e. new ECM synthesis and remodelling to provide a larger volume for myofibres. Thus mechanical stretching could tear, disrupt or mechanically alter the 'bag' ECM sufficiently to stimulate individual fibroblasts to produce new connective tissue for both repair and enlargement. In fact the exercise regimes which promote human skeletal muscle hypertrophy, which often include concentric contractions, as well as the mechanical stretching to promote muscle growth in animal models, are usually associated with damage to muscle (see Millward et al. 1994), as indicated by marked local oedema (Laurent $e t$ al. 1978). This damage may well involve actual connective tissue tearing. Catch-up growth would be explained in terms of bag filling, i.e. a malnourished child with wasted muscle has in fact lost myofibre contents rather than ECM and has relatively empty bags of a size which correspond to that necessary to maintain appropriate muscle mass for that particular bone length. The 'bag full' signal would coincide with restoration of normal weight for height when volume expansion and/or further protein deposition within the myofibre is inhibited. 
The most difficult part of this general mechanism is the nature of the eventual inhibition of myofibre protein deposition, i.e. the bag full signal which links cessation of muscle growth to cessation of long bone growth. One possibility relates to recent research on the relationship between cellular hydration, swelling and anabolic regulation. Haussinger \& Lang (1992) and Haussinger (1995) have shown that in hepatocytes, cell swelling acts like a proliferative anabolic signal with cell shrinkage being catabolic. Furthermore he believes that this may well be a general cellular control mechanism since dehydration (cell shrinkage) of skeletal muscle is associated with marked catabolism and muscle wasting (Haussinger et al. 1993). It might be that the bag full signal is loss of responsiveness to anabolic signals once total myofibre volume within the endomysial or perimysial sheath fills the available space.

\section{SUMMARY OF SKELETAL MUSCLE GROWTH REGULATION}

The key characteristics of skeletal muscle growth are

(i) mass is regulated at a size which varies with power 4 of the linear dimensions of the organism maintaining proportionality of strength with body weight;

(ii) growth rate is dependent on bone length growth which controls both the rate during normal growth and the target size as in catch-up growth;

(iii) target size can only be reached when dietary protein concentration is sufficient to exert an anabolic drive;

(iv) some physical activity (i.e. muscle work) is required for maximal phenotypic skeletal muscle mass to be achieved;

(v) passive muscle stretching by bone lengthening is the physiological stimulus for normal muscle growth, acting on protein deposition within the myofibre in concert with direct dietary effects, but acting as the sole influence on connective tissue growth;

(vi) expansion beyond the phenotypic size cannot normally occur possibly because the protein mass is rate limited by the connective tissue matrix which defines the myofibre volume.

\section{FOOD INTAKE REGULATION AND LEAN TISSUE GROWTH}

\section{ANIMAL STUDIES}

In order for a protein-stat mechanism to operate there is a requirement for an aminostatic component of appetite regulation in which food intake is adjusted to provide the protein needs for body protein growth or maintenance.

At the outset it is accepted that appetite regulation in general is poorly understood and the extent to which appetite is driven by an aminostatic mechanism as opposed to a glucose or caloriestatic mechanism is controversial and currently under intense investigation. From the perspective of the overall phenomenology of food intake regulation and lean tissue growth, the existence of an appetite mechanism driven by the demands for protein generated by LBM growth is consistent with the animal literature.

Webster (1993) recently reviewed food intake and energy partitioning during animal growth and concluded that the regulation of food intake is dominated by the impetus for lean tissue growth.

Webster's own work showed that female obese and lean Zucker rats fed ad lib. amounts of diets which had varying protein and fat contents deposited lean tissue (protein) at similar rates regardless of the diet or genotype. While fat deposition was much higher in the homozygote, nevertheless in each genotype fat deposition varied markedly with dietary composition. The main implications of this work according to Webster are 
(i) protein accretion is regulated with high precision;

(ii) food intake is adjusted to allow maximum protein accretion;

(iii) fat accretion is unregulated (although this can only be true within a specific genotype, since the homozygous Zucker rats run their appetite at a higher set point).

Thus the rate of protein accretion is the regulator of energy and protein intake, with protein, but not fat, growth regulated by appetite control. Webster argues that while this simple statement cannot always be generally true given that the rate of lean tissue growth varies according to age, sex, state of maturity, extent of previous inhibition and consequent catch-up potential, presence of growth promoters or growth promoting genes, nevertheless studies of the physiological manipulation of animal growth generally support it. Thus bovine and porcine data show that with either castration + anabolic steroids or with growth hormone, when the propensity for fat deposition is reduced hormonally then the target of protein deposition is achieved at lower food intakes. Pigs fed low protein diets ad lib. which cannot eat sufficient to satisfy their protein demand nevertheless make the attempt and get fatter whilst their weight for age falls. When offered a choice of a higher protein diet and allowed to catch-up, they select the high protein diet, increase their protein intake and exhibit compensatory growth with catch-up of both weight and protein content for age. Rats generally behave the same way although, as the authors' work has shown, the magnitude of any increased intakes of protein deficient diets is small and variable (e.g. Jepson et al. 1988). When malnourished rats are fed a range of protein intakes (3-20\%) ad lib., all groups fed $6 \%$ or more protein increased their food intakes above that of the very low protein (3\%) group and increased skeletal muscle growth (Yahya \& Millward, 1994). Furthermore the highest mean food intakes were consistently observed in the rats fed the minimum dietary protein concentration for maximal rates of muscle growth $(9 \%$ protein, although the differences in food intake between $9 \%$ and higher protein concentrations were small).

These appetite changes in the rat are in fact much less apparent than those observed in the human where there is a marked increase in appetite during catch-up growth. This is probably because, in the rat, normal growth is in any case very rapid with much higher levels of food intake than in the normally slow-growing human.

The extent to which protein deposition in muscle is the specific controlling influence of food intake, rather than protein deposition in the LBM in general, is not discussed by Webster (1993). However he does point out that the behaviour of the growth of visceral organs would indicate that these organs respond to, rather than control, food intake. Thus in transgenic giant mice (i.e. with the metallothionein-human growth hormone gene), which consume more food and are much heavier, liver is proportionately increased compared with other organs (its allometric relationship changing; its exponent increasing from 0.95 to 1.17). Similarly lean and obese pigs brought to the same body weight by varying food intakes show marked variation in relative liver and gut sizes, with liver and gut 44 or $32 \%$ larger in the high compared with low food intakes.

Webster's general hypothesis is that nutrient requirements of a growing animal are determined principally by its impetus for lean tissue growth: the partition of nutrients between protein, fat and heat become thereafter inevitable consequences of its physiological state and the availability of different nutrients. While the inclusion of fixed rates of heat production in this scheme (fixed according to rates of protein and fat deposition and a fixed maintenance cost) is debatable given the varying energetic cost of protein deposition reported in the rat by Coyer $e t$ al. (1987) and in the pig by Gurr et al. (1980), nevertheless Webster presents a powerful case.

Clearly these considerations relating to a LBM growth driven aminostatic appetite control mechanism need to be distinguished from food preference differences which can be 
observed between different diets with sufficient protein intakes. Thus in the growing rat appetite and meal size are dependent upon the dietary protein level only below the optimal requirement level. Preference for dietary protein will override flavouring for sweetness in a protein deficient diet but not above the requirement level (Mori et al. 1991). The experimental data are also derived from animal models in which varying physical activity and energy expenditure do not occur so that energy balance sensing appetite mechanisms are less important.

An experimental model which fits well with an aminostatic appetite mechanism linking dietary protein intake to the capacity for skeletal muscle growth is the severely zinc deficient rat. The widespread distribution and key importance of zinc metalloenzymes in cells means that zinc can be likened to an essential amino acid with tissue accretion not possible without it (Golden, 1988). The main feature of severe zinc deficiency is like that of a severe indispensable amino acid imbalance, i.e. anorexia and growth failure, which in the rat results in cycles of fasting induced wasting and refeeding (e.g. Chesters \& Quarterman, 1970; Giugliano \& Millward, 1984). Amino acids and their metabolites are often assumed to play key roles in mediating the anorexia because this response is abolished by lowering the dietary protein concentration and because zinc deficient rats show preference for low protein diets (O'Dell \& Reeves, 1988). Furthermore Chesters \& Will (1973) showed that the dietary protein effect on appetite inhibition was associated with intakes of the indispensable amino acids (methionine, phenylalanine, threonine and tryptophan). The usual interpretation of the cyclic fasting-feeding phenomenon with severe zinc deficiency is an appetite inhibition induced by changes in the pattern of plasma amino acids subsequent to inhibition of protein deposition and tissue growth by the zinc deficiency. This is eventually relieved after sufficient muscle wasting has occurred to release tissue zinc which then allows repletion of muscle protein and restoration of appetite (Guigliano \& Millward, 1987). However, a detailed sensing mechanism has yet to be identified.

\section{HUMAN STUDIES}

As far as human evidence for a link between food intake regulation and lean tissue skeletal muscle growth is concerned, the marked changes in appetite during nutritional rehabilitation is probably the best example. This allows intakes of energy dense foods equivalent to four times the resting metabolic rate, with a marked inhibition of appetite when catch-up has been achieved and weight/height is restored (Ashworth, 1974). Only in a small proportion does the marked inhibition of appetite when weight/height is restored not occur and these become obese (Waterlow, 1992). From the perspective of a protein-stat mechanism the explanation of these changes in appetite would be as follows. In the wasted musculature after any inhibition associated with infection or trauma has subsided, protein synthesis recovers quickly so that protein repletion becomes limited only by substrate provision, above a threshold (relatively low) dietary protein concentration. Amino acids are rapidly removed from the circulation postprandially and this increased net flow into muscle would by some unspecified mechanism result in marked stimulation of appetite and food intake which allows the accelerated growth rates so long as food intake is not limited by volume or viscosity. Increasing growth rates and food intakes will occur as long as amino acid demands for protein deposition exceed intake sufficiently to prevent free amino acid accumulation, and the diet contains sufficient energy to fuel the high cost of protein deposition. When skeletal muscle repletion has occurred, as far as is possible for the level of physical activity, the amino acid demand falls so that protein intake becomes excessive in relation to demand, appetite is inhibited, and there is resumption of normal rates of food intake, weight gain and protein deposition. 
While this is a logical interpretation of what is observed, experimental data to support or allow elaboration of this mechanism are sparse to say the least. Indeed the very high energy intakes required for the high rates of weight gain, and the effectiveness of energy dense formulae, have been taken as indicating that appetite may be energy driven in these children (Jackson \& Wooton, 1990). Clearly energy demands of rapid catch-up growth are high so that it is not surprising that early attempts to achieve catch-up with protein enriched diets which were not sufficiently energy dense failed (see Waterlow, 1992). The fact that these infants appear generally to deposit excessive fat (see above) would suggest that energy balance is not the regulator and is consistent with an aminostatic appetite mechanism. However, it might also reflect the high fat-carbohydrate ratio of these feeds and the relatively poor appetite control of fat intake. Thus unless the dietary protein-energy ratio is equal to or greater than the ratio which exactly matches energy needs for maintenance and growth at the growth rate allowed by the protein intake, there will be excess energy intake with consequent fat deposition. In other words, while relatively low protein-energy ratio diets are needed to stimulate appetite, since the P:E ratio of the requirement increases with the growth rate (Jackson \& Wooton, 1990), too low a ratio may result in excess fat gain.

In fact the crucial experiments to test whether appetite is driven by amino acid demands or energy demands have not been reported. These would involve feeding energy dense formulae with increasing protein concentrations and monitoring intakes. Studies in low birthweight infants have shown that tolerance of increasing dietary protein intakes was at its limit at maximal rates of protein accretion (Kashyap et al. 1988). In recent studies of catch-up growth in malnourished children, increasing the protein-energy ratio of an energy dense formula from 7.7 to $11.8 \%$ protein calories did result in a modest fall in voluntary energy intake daily from $165 \pm 7.8 \mathrm{kcals} / \mathrm{kg}$ to $155 \pm 18.5 \mathrm{kcals} / \mathrm{kg}$ (T. Forrester, A. A. Jackson \& D. J. Millward, unpublished results), and an apparent fall in the cost of growth and hence extent of fat deposition. This response, while not definitive, is suggestive of the importance of protein intake relative to demand as a controlling influence.

In summary then, food intake regulation has the following characteristics:

(i) nutrient requirements of a growing animal are determined principally by its impetus for lean tissue growth, with appetite and meal size dependent upon the dietary protein level at dietary protein concentrations below the optimal requirement level;

(ii) the marked changes in human appetite during nutritional rehabilitation are consistent with intake regulated to provide sufficient protein for skeletal muscle growth during the repletion of muscle tissue.

\section{CELLULAR MECHANISMS OF AMINOSTATIC APPETITE REGULATION}

The phenomenon of changes in appetite as a result of muscle wasting has not been investigated in a detailed way. Furthermore, while an aminostatic theory of appetite regulation has existed for 40 years (Melinkoff et al. 1956) with, at first sight, cogent mechanisms to explain influences of amino acid concentrations on neurotransmitters, there is no current consensus about how such aminostatic mechanisms work. Indeed, current human research on the regulation of appetite and satiety by carbohydrates, fats, and proteins suggests that the regulatory system is multifaceted and complex (e.g. Roehrig, 1991; Blundell et al. 1993). While many argue that dietary protein has a potent if not the most potent effect of all macronutrients on satiety (e.g. De Castro, 1987), short term effects of different amounts of protein, fats, and carbohydrates on satiety are in fact very difficult to demonstrate in human studies (e.g. De Graaf et al. 1992). 
In looking for a link between dietary protein and appetite regulation, it is the case that the aromatic amino acids (tryptophan, tyrosine, phenylalanine) are the biosynthetic precursors for the neurotransmitters serotonin (5-hydroxytryptamine, 5-HT), dopamine, and noradrenaline with histidine a precursor for histamine, so that aromatic amino acids can potentially influence neurological function.

5-HT neurones certainly play an important part in the regulation of appetite, with serotoninergic agents (5-HT releasers and direct agonists) inducing a prompt anorexia and as a result being used to control obesity and eating disorders (e.g. Blundell \& Hill, 1992). 5-HT neurones are widely distributed both peripherally, especially in the enteric nervous system and involved in many aspects of visceral function, and in many separate regions of the brain (Blundell, 1992). Of the several 5-HT systems that may signal feeding responses, at least two specific metabolic mechanisms exist, i.e. glucose sensitive neurones in the liver, brainstem and forebrain, and the potential regulation of neuronal 5-HT levels via changes in tryptophan uptake into the brain. The key variable is not the absolute concentration of tryptophan but the ratio of tryptophan to the large neutral amino acids (i.e. branched chain and aromatic amino acids, LNAA) which compete with tryptophan for the transporter (Fernstrom \& Wurtman, 1972; Fernstrom \& Fernstrom, 1993) with consequent regulation of 5-HT synthesis (Fernstrom, 1991; Fernstrom \& Fernstrom, 1995).

Since plasma amino acid levels are a function of dietary protein and glucose intake, via insulin mediated inhibition of endogeneous proteolysis, then modulation of brain 5-HT concentration can in theory be achieved through dietary intakes of both protein and carbohydrate. Recent studies have involved normal and obese women treated with fluoxetine, a brain 5-HT re-uptake blocker. The breakfast induced changes in plasma tryptophan-LNAA ratios and associated differences in macronutrient composition of subsequent food intakes clearly demonstrated the importance of the brain 5-HT mediated control of carbohydrate consumption in normal weight and obese humans (Pijl et al. 1993). Also studies of postprandial satiety and plasma amino acids in male subjects after the ingestion of beef, chicken and fish indicated that the greater satiety after the fish meal was correlated with serotoninergic activity due to differences observed in the postprandial tryptophan-LNAA ratio (Uhe et al. 1992).

However, as far as detailed mechanistic studies are concerned, most of which derive from rat studies, there is no current consensus of the importance of serotoninergic mechanisms of appetite control in relation to regulation of protein intake. There is no dispute that, in response to intakes of carbohydrate with or without protein, differences occur in the plasma tryptophan-LNAA ratio, and brain 5-HT and its metabolites (e.g. Harper \& Peters, 1989; Fernstrom \& Fernstrom, 1995). The main dispute is the extent to which this mechanism can monitor varying protein concentrations in the diet. In the rat there is a considerable body of work demonstrating protein selection and varying food intake in relation to both concentration and amino acid imbalance (e.g. Harper \& Peters, 1989), but the associations between brain 5-HT concentrations and varying protein concentration and amino acid imbalance are weak. Harper \& Peters (1989) argue from their studies that while rats offered meals with increasing protein intakes demonstrate marked increases in plasma amino acids, brain amino acid concentrations change relatively little. Indeed, in response to single meals of varying protein concentration from 0 to $55 \%$ casein, plasma tryptophan-LNAA ratios and brain 5-HT are elevated only in the absence of any protein, with lower levels of both at all concentrations from 5 to $55 \%$. Fernstrom \& Fernstrom (1995) recently reported that with single meals of increasing protein content there was increased 5-HT synthesis in brain in response to both a protein free and $6 \%$ protein meal but no increase at higher protein (up to $40 \%$ protein). This is consistent with Harper \& Peters' view that increased 5-HT accounts for the satiating effect of carbohydrate but not 
protein. Indeed, it would appear that with growing rats the threshold of any dietary protein related satiety mechanism is very high. Harper \& Peters (1989) concluded that since animals can adapt their pathways of amino acid oxidation to match intakes over a wide range of intakes there is no need to regulate protein intake finely, with survival value coming only from the ability to identify very low and very high intakes. Furthermore in rats selecting between 10 and $60 \%$ protein diets, injection with sufficient tryptophan to markedly increase brain tryptophan levels showed no change in their protein selection. Thus Harper \& Peters (1989) argue that the main feature of the regulation appears to be a mechanism designed to control the overall pattern of free amino acids in tissue pools with sensing mechanisms based on a wide range of metabolic responses to imbalances. Certainly in rats fed low protein diets containing disproportionate amounts of LNAA devoid of tryptophan or histidine (tryptophan or histidine imbalance), the depressed food intakes were correlated with brain concentrations of the limiting amino acid, tryptophan or histidine, but not consistently with concentrations of 5-HT and 5-hydroxyindole-3-acetic acid (Tackman et al. 1990). Thus these authors concluded that while competition among amino acids for uptake into brain appears to be involved in the feeding response of the rat to dietary disproportions of amino acids, this response is not directly related to changes in brain concentrations of 5-HT and 5-hydroxyindole-3-acetic acid (Tackman et al. 1990).

Gietzen (1993) recently reviewed the neural mechanisms involved in the responses to amino acid deficiency, emphasizing the importance of both central and peripheral responses, with changes in protein synthesis possibly mediated by noradrenaline and cAMP in the anterior prepyriform cortex acting as one amino acid chemosensor and with serotoninergic mechanisms and $5-\mathrm{HT}_{3}$ receptors which can sense both gastrointestinal and hepatoportal amino acid imbalances involved in learned aversion responses.

The question can be posed as to the appropriateness of the rapidly growing rodent as a model for appetite mechanisms in the slow growing human.

There is no doubt that the higher maintenance energy requirement and the rapid growth rate of the rat compared with the human infant or adult will influence the magnitude of changes in both protein and energy intakes likely to occur in the situations in which the protein-stat would operate. Thus in contrast to a 3-fold increase in energy intake and 20fold increase in rate of protein deposition observed in the child during catch-up, in the rat the transition from a very low protein diet which allowed no growth to maximal catch-up growth involves an increase of $77 \%$ in food intake, and increases in muscle growth rates of only $50 \%$ above the normal growth rate (Millward et al. 1975; Yahya \& Millward, 1994). Certainly the responses of the adult rat are more in line with an aminostat appetite mechanism as postulated in the protein-stat. Thus adult rats avoided $50 \%$ protein and consumed a protein free diet until they lost weight; they then selected a diet of $30-40 \%$ protein (Leathwood, 1987).

Taken together, while these rat and human studies show that aminostatic mechanisms are important components of appetite control and may well act within a protein-stat mechanism, details of how they do remain to be unravelled. Specifically the sensory mechanisms which activate the afferent signal remain unknown although it is likely that absolute or relative free amino acid concentrations are involved. Virtually no experimental information has been derived from studies investigating appetite responses during catch-up growth. For this reason it is not currently possible to identify detailed experimental support for the working hypothesis that when amino acid net flow from the free pool into skeletal muscle protein is greater than that of entry from food intake, satiety will be inhibited and hunger induced by some mechanism sensing an apparent body deficit of amino acids. Whatever this mechanism is, we know that it is very powerful in these circumstances of loss and repletion of the LBM. When the LBM is not depleted, then it would appear that 
appetite mechanisms that sense energy balance become more important and since most research has involved such individuals then it is not surprising that aminostatic mechanisms are often not observed.

\section{THE PROTEIN-STAT AND WHOLE BODY GROWTH COORDINATION}

On the basis of the above, a protein-stat mechanism can be constructed as in Fig. 10. The system under control is the whole body protein mass (loose control) of which the major component, skeletal muscle protein, is tightly controlled. There is a dietary controller, which is the minimum protein concentration required to exert an anabolic drive or regulatory influence on linear bone growth and muscle myofibre growth, and internal controllers which are linear bone growth which sets through passive stretch, muscle growth capacity at the level of the ECM which defines myofibre volume, and appetite control which allows protein intake to match capacity. With cessation of linear bone growth at epiphyseal fusion in the young adult, skeletal muscle connective tissue growth ceases, limiting further volume expansion of myofibres, and cannot be stimulated by dietary protein intake alone. Modest depletion of muscle protein during the feeding-fasting diurnal cycling may not require specific appetite regulation to allow for repletion so that in this sense the proteinstat is likely to be operating at or near the 'bag-full' state throughout most of normal life for humans, with aminostatic appetite stimulation occurring only during early postnatal life and during growth spurts. Loss of skeletal muscle protein during disease or malnutrition is readily reversible, possibly because the connective tissue framework is not lost. Thus catch-up growth in terms of restoration of weight for height occurs when a substantial deficit in the phenotypic skeletal muscle mass-bone length ratio has occurred. In this case repletion is achieved through appetite stimulation. The origin of the afferent signal is the increased amino acid net flow into muscle sensed by as yet unidentified mechanisms (possibly changes in the relative and/or absolute concentrations of free amino acids). Catch-up growth is only a special case of normal growth in that the rate of net deposition (bag filling) is sufficiently greater than normal to provoke increased appetite. However, once the phenotypic skeletal muscle mass-bone length ratio has been restored any further growth will be limited by the need for new connective tissue deposition, and this is in turn limited by bone length growth. The reduced amino acid net flow into muscle protein through inhibition of net protein synthesis by some unknown mechanism responding to the 'bag full' signal will reduce appetite to the level appropriate for the growth rate. In addition to the protein-stat controllers, muscle contraction during normal physical activity acts as an additional fine controller to mediate maximal muscle protein content by an unknown mechanism.

Once a linkage between longitudinal bone growth and skeletal muscle growth is established, coordination of growth of the remaining organs is in many ways less of a challenge. The size of the visceral organs will reflect mainly the functional demand for the organ imposed by the protein intake level. This in turn is a function of the metabolic demands of growth, organ maintenance and external work, and the dietary protein concentration. With the cellular evidence for a controlling influence of stretching on fibroblast activity (Bishop et al. 1995), it is reasonable to argue that the growth of the skin, like that of skeletal muscle, involves a stretch mechanism exerted through the whole body volume increase subsequent to growth of all other organs.

There are important unanswered questions about the normal range and upper limits to splanchnic organ size. Munro (1964) noted from early animal data on the labile protein 


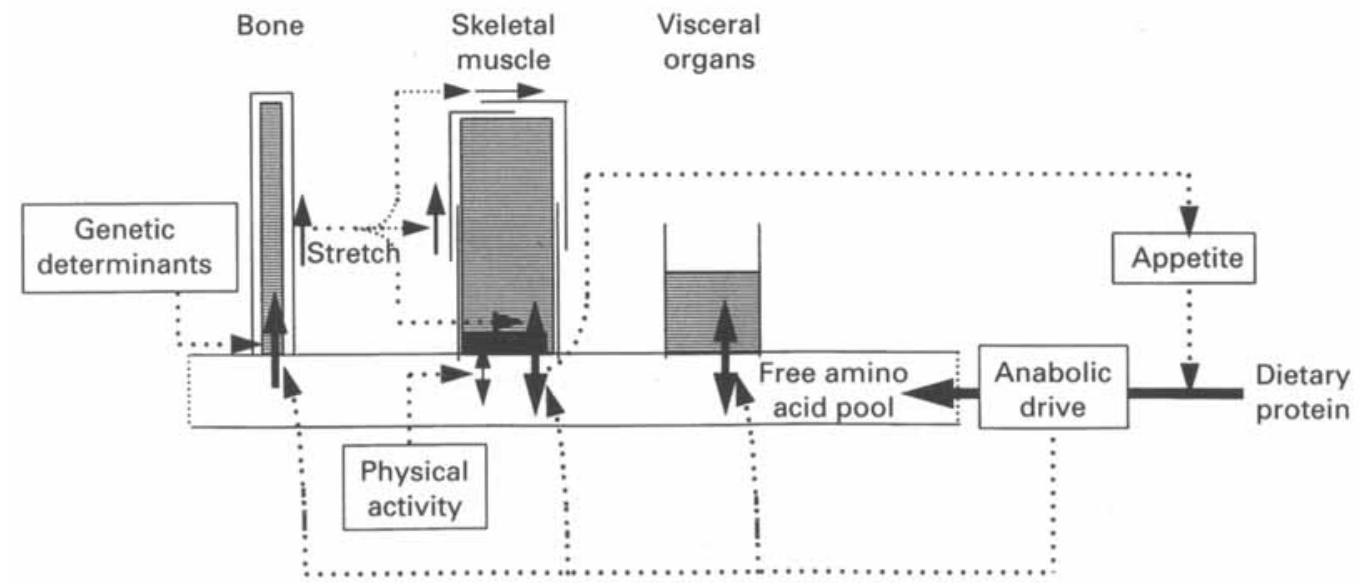

Fig. 10. The protein-stat. Whole body protein content is controlled through an aminostatic appetite mechanism, acting primarily to maintain skeletal muscle mass at a level set by the linear dimensions of the organism. Bone lengthening occurs at rates determined by genetic programming (canalization) and an appropriate anabolic drive, exerted by dietary protein. Net protein deposition in skeletal muscle during growth requires specific activation of new connective tissue synthesis and myofibrillar protein deposition by passive stretching of skeletal muscle by bone length growth. Because muscle connective tissue surrounds individual and groups of myofibres as well as the whole muscle, like a bag, it limits myofibre volume. Thus during growth, connective tissue remodelling, bag enlargement, must occur to allow increased myofibre diameter and length. With connective tissue growth limited solely by passive stretch, the amount of muscle connective tissue, bag size, and consequent muscle size will be regulated at a phenotypic muscle weight-bone length ratio. Provision of amino acids to allow muscle to increase to its phenotypic size, bag filling, is regulated through appetite stimulation in response to net amino acid flow into muscle at a rate greater than the dietary intake. Maximal phenotypic muscle size also requires some physical activity. Muscle growth, i.e. bag enlargement, ceases when bone length growth ceases. The growth of most other organs is secondary to this main interaction, determined primarily by the level of protein intake and the consequent metabolic work and functional demand for the organ, and is not specifically limited in size. Operation of the protein-stat occurs only at dietary protein levels sufficient to provide both substrate and an appropriate anabolic drive acting on protein deposition in bone, muscle myofibres (but not connective tissue synthesis), and other organs.

reserves that liver protein increased continuously with increasing dietary protein intake up to very high intakes, albeit at a decreasing rate. In recent studies of subjects changing from a high $(1.82 \mathrm{~g} / \mathrm{kg})$ to moderate $(0.77 \mathrm{~g} / \mathrm{kg})$ protein diet, a protein intake range covering most of the population, the negative nitrogen balance over $9 \mathrm{~d}$ was equivalent to a loss of about $0.82 \mathrm{~kg} \mathrm{LBM}$ (Quevedo et al. 1994). Since $\mathrm{N}$ balance equilibrium had not been achieved it might be assumed that about $1 \mathrm{~kg} \mathrm{LBM}$ was lost in total. This implies that the LBM may vary by about $2 \%$ according to the protein intake. However, with food intake regulated by both energy and protein sensing mechanisms and with dietary protein composition not normally varying markedly, it can be assumed that appetite regulation in effect controls splanchnic protein mass.

Growth control can then be seen in terms of a primary regulation of long bone growth mediated through the nutritional anabolic drive allowing the genetically determined canalized rate and extent of bone growth to be achieved. Skeletal muscle growth is then mainly a secondary response, controlled and limited by the rate of bone growth acting through the stretch mechanism. The size and activity of muscle will influence energy expenditure and needs and influence food intake by the appetite mechanisms which may also be controlled by the genetic programming (i.e. linked to periodic growth spurts). Food intake will directly determine the size of the visceral tissues (i.e. liver, gut, kidneys), will 
actively and permissively influence muscle growth and will complete the circle by actively influencing bone growth.

Clearly much of the above is speculative and oversimplified. The identification of catchup growth as simply one component (bag-filling) of normal growth and stretch induced hypertrophy as the same as normal growth is the most obvious oversimplification. While the emerging cellular mechanisms are beginning to provide support there are many unanswered questions: the mechanisms for sensing increased net flow of amino acid into muscle, the 'bag full' signal, the degree of control of body protein by the protein-stat in adults fed increasing amounts of dietary protein. While a relative stability of the skeletal muscle mass over a wide range of protein intakes is observed, the quantitative limits of that stability have yet to be established. With the possibility of continued expansion of the splanchnic component of the LBM with increasing protein intakes, and loss at marginally low levels, it is likely that the overall LBM does vary with protein intake to some extent. However, with skeletal muscle effectively determining food intake through its large contribution to overall energy expenditure, it can be argued that there is no need to devise any other specific strategy for control of the remainder of the LBM.

The author gratefully acknowledges the valuable contributions from collaborators and students during the development of the ideas expressed here, especially Dr Paul Pacy, Dr D. Halliday, Dr Zainal Yahya, Dr Peter Bates, Dr Gill Price and Dr Marcello Quevedo. Discussion with Dr Gill Bishop is also gratefully acknowledged. The work was supported by the Nestlé Foundation, the Leverhulme Trust, the Nutritional Consultative Committee and the British Council.

\section{REFERENCES}

Allen, L. H. (1994). Nutritional influences on linear growth: a general review. European Journal of Clinical Nutrition 48, S75-S89.

Allen, R. E. \& Rankin, L. L. (1990). Regulation of satellite cells during skeletal muscle growth and development. Proceedings of the Society for Experimental Biology and Medicine 194, 81-86.

Ashworth, A. (1974). Ad lib. feeding during recovery from malnutrition. British Journal of Nutrition 31, $109-112$.

Ashworth, A. \& Millward, D. J. (1986). Catch-up growth in children. Nutrition Reviews 44, 157-163.

Bishop, J. E., Butt, R. P. \& Low, R. B. (1995). The effect of mechanical forces on cell function: implications for pulmonary vascular remodelling due to hypertension. In Pulmonary Vascular Remodelling, pp. 213-239 [J. Bishop, J. Reeves and G. Laurent, editors]. London: Portland Press.

Blundell, J. E. (1992). Serotonin and the biology of feeding. American Journal of Clinical Nutrition 55 (Suppl. 1), 155S-159S.

Blundell, J. E. \& Hill, A. J. (1992). Dexfenfluramine and appetite in humans. International Journal of Obesity 16, S51-S59.

Blundell, J. E., Lawton, C. L. \& Hill, A. J. (1993). Mechanisms of appetite control and their abnormalities in obese patients. Hormone Research 39 (Supplement 3), 72-76.

Brooke, O. G. \& Wheeler, E. F. (1976). High energy feeding in protein-energy malnutrition. Archives of Disease in Childhood 51, 968-971.

Chesters, J. K. \& Quarterman, J. (1970). Effects of zinc deficiency on food intake and feeding patterns of rats. British Journal of Nutrition 24, 1061-1069.

Chesters, J. K. \& Will, M. (1973). Some factors controlling food intake by zinc-deficient rats. British Journal of Nutrition 30, 555-566.

Coyer, P. A., Rivers, J. P. W. \& Millward, D. J. (1987). The effect of dietary protein and energy restriction on heat production and growth costs in the young rat. British Journal of Nutrition 58, 73-85.

De Castro, J. M. (1987). Macronutrient relationships with meal patterns and mood in the spontaneous feeding behavior of humans. Physiology and Behavior 39, 561-569.

De Graaf, C., Hulshof, T., Weststrate, J. A. \& Jas, P. (1992). Short-term effects of different amounts of protein, fats, and carbohydrates on satiety. American Journal of Clinical Nutrition 55, 33-38.

Deriaz, O., Fournier, G., Tremblay, A., Despres, J. P. \& Bouchard, C. (1992). Lean body mass composition and resting energy expenditure before and after long-term overfeeding. American Journal of Clinical Nutrition 56, 840-847. 
Dickerson, J. W. T. \& McCance, R. A. (1961). Severe undernutrition in growing and adult animals. 8. The dimensions and chemistry of the long bones. British Journal of Nutrition 15, 567-576.

Dix, D. J. \& Eisenberg, B. R. (1990). Myosin mRNA accumulation and myofibrillogenesis at the myotendinous junction of stretched muscle fibers. Journal of Cell Biology 111, 1885-1894.

Essig, D. A., Devol, D. L., Bechtel, P. J. \& Trannel, T. J. (1991). Expression of embryonic myosin heavy chain mRNA in stretched adult chicken skeletal muscle. American Journal of Physiology 260, C1325-C1331.

Felig, P. (1981). Inter-organ amino acid exchange. In Nitrogen Metabolism in Man, pp. 45-61 [J. C. Waterlow and J. M. L. Stephen, editors]. London: Applied Science.

Fernstrom, J. D. (1991). Effects of the diet and other metabolic phenomena on brain tryptophan uptake and serotonin synthesis. Advances in Experimental Medicine and Biology 294, 369-376.

Fernstrom, J. D. \& Wurtman, R. J. (1972). Brain serotonin content: physiological regulation by plasma neutral amino acids. Science 178, $414-416$.

Fernstrom, M. H. \& Fernstrom, J. D. (1993). Large changes in serum free tryptophan levels do not alter brain tryptophan levels: studies in streptozotocin-diabetic rats. Life Sciences 52, 907-916.

Fernstrom, M. H. \& Fernstrom, J. D. (1995). Brain tryptophan concentrations and serotonin synthesis remain responsive to food consumption after the ingestion of sequential meals. American Journal of Clinical Nutrition 61, 312-319.

Forbes, G. B. (1985). Body composition as affected by physical activity and nutrition. Federation Proceedings 44, 343-347.

Forbes, G. B. (1988). Body composition: influence of nutrition, disease, growth and aging. In Modern Nutrition in Health and Disease, pp. 533-556 [M. E. Shils and V. R. Young, editors]. Philadelphia, PA: Lea \& Febiger.

Gietzen, D. W. (1993). Neural mechanisms involved in the responses to amino acid deficiency. Journal of Nutrition $123,610-625$.

Giugliano, R. \& Millward, D. J. (1984). Growth and zinc homeostasis in the severely Zn-deficient rat. British Journal of Nutrition 52, 545-560.

Giugliano, R. \& Millward, D. J. (1987). The effects of severe zinc deficiency on protein turnover in muscle and thymus. British Journal of Nutrition 57, 139-155.

Golden, B. E. (1989). Zinc in cell division and tissue growth: physiological aspects. In Zinc in Human Biology, pp. 173-181 [C. F. Mills, editor]. London: Springer-Verlag.

Golden, B. E. \& Golden, M. H. N. (1985). Effect of zinc supplementation on the composition of newly synthesized tissue in children recovering from malnutrition. Proceedings of the Nutrition Society 44, 110A.

Golden, M. H. N. (1988). The role of individual nutrient deficiencies in growth retardation of children as exemplified by zinc and protein. In Linear Growth Retardation in Less Developed Countries (Nestle Nutrition Workshop Series, vol. 14), pp. 143-163 [J. C. Waterlow, editor]. New York: Raven Press.

Golden, M. H. N. (1994). Is complete catch-up possible for stunted malnourished children? European Journal of Clinical Nutrition 48, S58-S71.

Goldspink, D. F., Easton, J., Winterburn, S. K., Williams, P. E. \& Goldspink, G. E. (1991). The role of passive stretch and repetitive electrical stimulation in preventing skeletal muscle atrophy while reprogramming gene expression to improve fatigue resistance. Journal of Cardiac Surgery 6, 218-224.

Goss, R. J. (1978). Adaptive mechanisms of growth control. In Human Growth, vol. 1, Principles and Prenatal Growth, pp. 3-21 [F. Falkner and J. M. Tanner, editors]. New York: Plenum Press.

Gould, R. P. (1973). The microanatomy of muscle. In The Structure and Function of Muscle, 2nd edn, vol. 2, Structure Part 2, pp. 185-241 [G. H. Bourne, editor]. New York: Academic Press.

Graham, G. G., Lembcke, J. \& Morales, E. (1990). Quality-protein maize as the sole source of dietary protein and fat for rapidly growing young children. Pediatrics $85,85-91$.

Gurr, M. I., Mawson, R., Rothwell, N. J. \& Stock, M. J. (1980). Effects of manipulating dietary protein and energy intake on energy balance and thermogenesis in the pig. Journal of Nutrition 110, 532-542.

Hansen-Smith, F. M., Picou, D. \& Golden, M. H. N. (1979). Growth of muscle fibres during recovery from severe malnutrition in Jamaican infants. British Journal of Nutrition 41, 275-282.

Harper, A. E. \& Peters, J. C. (1989). Protein intake, brain amino acid and serotonin concentrations and protein self-selection. Journal of Nutrition 119, 677-689.

Haussinger, D. (1995). Regulation of metabolism by changes in cellular hydration. Clinical Nutrition 14, 4-12.

Haussinger, D. \& Lang, F. (1992). Cell volume and hormone action. Trends in Pharmacological Sciences 13, 371-373.

Haussinger, D., Roth, E., Lang, F. \& Gerok, W. (1993). Cellular hydration state: an important determinant of protein catabolism in health and disease. Lancet 341, 1330-1332.

Heinig, M. J., Nommsen, L. A., Peerson, J. M., Lonnerdal, B. \& Dewey, K. G. (1993). Energy and protein intakes of breast-fed and formula-fed infants during the first year of life and their association with growth velocity: the DARLING study. American Journal of Clinical Nutrition 58, 152-161

Jackson, A. A. \& Wooton, S. A. (1990). The energy requirement of growth and catch-up growth. In Activity, Energy Expenditure and Energy Requirement of Infants and Children, I/D/E.C.G. [B. Schurch and N. S. Scrimshaw, editors]. Lausanne: I/D/E/C/G.

Jepson, M. M., Bates, P. C. \& Millward, D. J. (1988). The role of insulin and thyroid hormones in the regulation 
of muscle growth and protein turnover in response to dietary protein in the rat. British Journal of Nutrition 59 , $397-415$.

Kabir, I., Butler, T., Underwood, L. E. \& Rahman, M. M. (1992). Effects of a protein-rich diet during convalescence from shigellosis on catch-up growth, serum proteins, and insulin-like growth factor-I. Pediatric Research 32, 689-692.

Kabir, I., Malek, M. A., Mazumber, R. N., Rahman, M. M. \& Mahalanabis, D. (1993). Rapid catch-up growth of children fed a high-protein diet during convalescence from shigellosis. American Journal of Clinical Nutrition 57, 441-445.

Kashyap, S., Schulze, K. F., Forsyth, M., Zucker,C., Dell, R. B., Ramakrishnan, R. \& Heird, W. C. (1988). Growth, nutrient retention and metabolic response in low birth weight infants fed varying intakes of protein and energy. Journal of Pediatrics 113, 713-721.

Laurent, G. J. \& Millward, D. J. (1980). Protein turnover during skeletal muscle hypertrophy. Federation Proceedings 39, 42-47.

Laurent, G. J., Sparrow, M. P., Bates, P. C. \& Millward, D. J. (1978). Turnover of muscle protein in the fowl. Collagen content and turnover in cardiac and skeletal muscles of adult fowl and the changes during stretchinduced growth. Biochemical Journal 176, 419-427.

Leathwood, P. D. (1987). Tryptophan availability and serotonin synthesis. Proceedings of the Nutrition Society 46, 143-156.

McCusker, R. H. \& Clemmons, D. R. (1988). Insulin-like growth factor binding protein secretion by muscle cells: effect of cellular differentiation and proliferation. Journal of Cellular Physiology 137, 505-512.

Mack, P. B., Vose, G. P., Kinard, C. L. \& Campbell, H. B. (1962). Effects of lysine-supplemented diets on growth and skeletal density of preadolescent children. American Journal of Clinical Nutrition 11, $255-262$.

Martorell, R. (1985). Child growth retardation: a discussion of its causes and its relationships to health. In Nutritional Adaptation in Man, pp. 13-17 [K. L. Blaxter and J. C. Waterlow, editors]. London: John Libby.

Melinkoff, S. M., Frankland, M., Boyle, D. \& Greipal, M. (1956). Relationship between serum amino acid concentration and fluctuations in appetite. Journal of Applied Physiology 8, 535-538.

Millward, D. J. (1989). The endocrine response to dietary protein : the anabolic drive on growth. In Milk Proteins, pp. 49-59 [C. A. Barth and E. Schlimme, editors]. Darmstadt: Steimkopff Verlag.

Millward, D. J. (1990). The hormonal control of protein turnover. Clinical Nutrition 9, 115-126.

Millward, D. J. (1995). Insulin and the regulation of amino acid catabolism and protein turnover. In Amino Acid Metabolism in Health and Disease, pp. 127-136 [L. Cynober, editor]. Boca Raton, FL: CRC Press.

Millward, D. J., Bowtell, J. L., Pacy, P. \& Rennie, M. J. (1994). Physical activity, protein metabolism and protein requirements. Proceedings of the Nutrition Society 53, 223-240.

Millward, D. J., Garlick, P. J., Stewart, R. J. C., Nnanyelugo, D. O. \& Waterlow, J. C. (1975). Skeletal-muscle growth and protein turnover. Biochemical Journal 150, 235-243.

Millward, D. J. \& Rivers, J. P. W. (1989). The need for indispensable amino acids: the concept of the anabolic drive. Diabetes and Metabolism Reviews 5, 191-212.

Millward, D. J. \& Waterlow, J. C. (1978). Effect of nutrition on protein turnover in skeletal muscle. Federation Proceedings 37, 2283-2290.

Mohan, S., Bautista, C. M., Wergedal, J. \& Baylink, D. J. (1990). Isolation of an inhibitory insulin-like growth factor (IGF) binding protein from bone-cell-conditioned medium: a potential local regulator of IGF action. Proceedings of the National Academy of Sciences of the USA 86, 8338-8342.

Mori, M., Kawada, T. \& Torii, K. (1991). Appetite and taste preference in growing rats given various levels of protein nutrition. Brain Research Bulletin 27, 417-422.

Munro, H. N. (1964). General aspects of the regulation of protein metabolism by diet and by hormones. In Mammalian Protein Metabolism, vol. 2, pp. 381-481 [H. N. Munro and J. B. Allison, editors]. London: Academic Press.

Nilsson, A., Ohlsson, C., Isaksson, O. G. P., Lindahl, A. \& Isgaard, J. (1994). Hormonal regulation of longitudinal bone growth. European Journal of Clinical Nutrition 48 (Supplement 1), S150-S160.

O'Dell, B. L. \& Reeves, P. G. (1988). Zinc status and food intake. In Zinc in Human Biology, pp. 173-181 [C. F. Mills, editor]. London: Springer-Verlag.

Paik, H. Y., Hwang, S. H. \& Lee, S. P. (1992). Comparative analysis of growth, diet, and urinary N excretion in elementary school children from urban and rural areas of Korea. International Journal of Vitamin and Nutrition Research 62, 83-90.

Parker, D. F., Round, J. M., Sacco, P. \& Jones, D. A. (1990). A cross-sectional survey of upper and lower limb strength in boys and girls during childhood and adolescence. Annals of Human Biology 17, 199-212.

Pijl, H., Koppeschaar, H. P. F., Cohen, A. F., Iestra, J. A., Schoemaker, H. C., Frolich, M., Onkenhout, W. \& Meinders, A. E. (1993). Evidence for brain serotonin-mediated control of carbohydrate consumption in normal weight and obese humans. International Journal of Obesity 17, 513-520.

Price, G. M., Halliday, D., Pacy, P. J., Quevedo, M. R. \& Millward, D. J. (1994a). Nitrogen homoeostasis in man. 1. Influence of protein intake on the amplitude of diurnal cycling of body nitrogen. Clinical Science 86 , 91-102.

Price, J. S., Oyajobi, B. O. \& Russell, R. G. G. (1994b). The cell biology of bone growth. European Journal of Clinical Nutrition 48, S131-S149. 
Quevedo, M. R., Price, G. M., Halliday, D., Pacy, P. J. \& Millward, D. J. (1994). Nitrogen homoeostasis in man. 3. Diurnal changes in nitrogen excretion, leucine oxidation and whole body leucine kinetics during a reduction from a high to a moderate protein intake. Clinical Science 86, 185-193.

Picou, D., Reeds, P. J., Jackson, A. A. \& Poulter, N. (1976). The measurement of muscle mass in children using $\left[{ }^{15} \mathrm{~N}\right]$ creatine. Pediatric Research 10, 184-188.

Roehrig, K. L. (1991). The influence of food on food intake: methodological problems and mechanisms of action. Critical Reviews in Food Science and Nutrition 30, 575-597.

Russell, B., Dix, D. J., Haller, D. L. \& Jacobs, E. L. J. (1992). Repair of injured skeletal muscle: a molecular approach. Medicine and Science in Sports and Exercise 24, 189-196.

Sadoshima, J. \& Izumo, S. (1993). Mechanical stretch rapidly activates multiple signal transduction pathways in cardiac myocytes: potential involvement of an autocrine/paracrine mechanism. EMBO Journal 12, $1681-1692$.

Tackman, J. M., Tews, J. K. \& Harper, A. E. (1990). Dietary disproportions of amino acids in the rat: effects on food intake, plasma and brain amino acids and brain serotonin. Journal of Nutrition 120, 521-531.

Tanner, J. M. (1979). A concise history of growth studies from Buffon to Boas. In Human Growth: a Comprehensive Treatise, vol. 3, Neurobiology and Nutrition, pp. 515-593 [F. Faulkner and J. M. Tanner, editors]. New York: Plenum Press.

Tirapegui, J. O., Yahya, Z. A. H., Bates, P. C. \& Millward, D. J. (1994). Dietary energy, glucocorticoids, and the regulation of long bone and muscle growth in the rat. Clinical Science 87, 599-606.

Uhe, A. M., Collier, G. R. \& O'Dea, K. (1992). A comparison of the effects of beef, chicken and fish protein on satiety and amino acid profiles in lean male subjects. Journal of Nutrition 122, 467-472.

Viteri, F. E. \& Torun, B. (1981). Nutrition physical activity and growth. In The Biology of Normal Growth, pp. 265-273 [M. Ritze et al., editors]. New York: Raven Press.

Waterlow, J. C. (1992). Protein Energy Malnutrition. London: Edward Arnold.

Waterlow, J. C., Garlick, P. J. \& Millward, D. J. (1978). Protein Turnover in Mammalian Tissues and in the Whole Body. Amsterdam: Elsevier/North-Holland Biomedical Press.

Webster, A. J. F. (1993). Energy partitioning, tissue growth and appetite control. Proceedings of the Nutrition Society 52, 69-76.

Winchester, P. K. \& Gonyea, W. J. (1992). Regional injury and the terminal differentiation of satellite cells in stretched avian slow tonic muscle. Developmental Biology 151, 459-472.

Yahya, Z. A. H., Bates, P. C. \& Millward, D. J. (1990). Responses to protein deficiency of plasma and tissue insulin-like growth factor-1 levels and proteoglycan synthesis rates in rat skeletal muscle and bone. Journal of Endocrinology 127, 497-503.

Yahya, Z. A. H. \& Millward, D. J. (1994). Dietary protein and the regulation of long bone and muscle growth in the rat. Clinical Science 87, 213-224.

Yahya, Z. A. H., Tirapegui, J. O., Bates, P. C. \& Millward, D. J. (1994). Influence of dietary protein, energy and corticosteroids on protein turnover, proteoglycan sulphation and growth of long bone and skeletal muscle in the rat. Clinical Science $87,607-618$.

Yan, Z., Biggs, R. B. \& Booth, F. W. (1993). Insulin-like growth factor immunoreactivity increases in muscle after acute eccentric contractions. Journal of Applied Physiology 74, 410-414. 